\title{
Immunology of Pediatric HIV Infection
}

\author{
Nicole H. Tobin ${ }^{1}$ and Grace M. Aldrovandi ${ }^{1,2}$ \\ ${ }^{1}$ Children's Hospital Los Angeles, Los Angeles, CA, USA \\ ${ }^{2}$ The Saban Research Institute, University of Southern California, Los Angeles, CA, USA
}

\section{Summary}

\begin{abstract}
Most infants born to human immunodeficiency virus (HIV)-infected women escape HIV infection. Infants evade infection despite an immature immune system and, in the case of breastfeeding, prolonged repetitive, exposure. If infants become infected, the course of their infection and response to treatment differs dramatically depending upon the timing (in utero, intrapartum, or during breastfeeding) and potentially the route of their infection. Perinatally acquired HIV infection occurs during a critical window of immune development. HIV's perturbation of this dynamic process may account for the striking age-dependent differences in HIV disease progression. HIV infection also profoundly disrupts the maternal immune system upon which infants rely for protection and immune instruction. Therefore, it is not surprising that infants who escape HIV infection still suffer adverse effects. In this review, we highlight the unique aspects of pediatric HIV transmission and pathogenesis with a focus on mechanisms by which HIV infection during immune ontogeny may allow discovery of key elements for protection and control from HIV.
\end{abstract}

\section{Keywords}

HIV; children; neonatal; gut microbiota; breast milk; Th17; regulatory T cells

\section{Introduction}

Most children born to human immunodeficiency virus-1 (HIV)-infected women do not become infected. Infants evade infection despite an immature immune system and, in the case of breastfeeding prolonged repetitive, exposure. If infants become infected, the course of their infection and response to treatment differs dramatically depending upon the timing and potentially the route of their infection. Perinatally acquired HIV infection occurs during a critical window of immune development. HIV's perturbation of this dynamic process may account for the striking age-dependent differences in HIV disease progression. HIV infection also profoundly disrupts the maternal immune system upon which infants rely for protection and immune instruction. Therefore, it is not surprising that infants who escape HIV infection still suffer adverse effects. In this review, we highlight the unique aspects of pediatric HIV transmission and pathogenesis with a focus on mechanisms by which HIV infection during immune ontogeny may allow discovery of key elements for protection and control from HIV.

Correspondence to: Grace M. Aldrovandi, Department of Pediatrics, Children's Hospital Los Angeles, The Saban Research Institute, University of Southern California, 4650 Sunset Blvd., MS\#51, Los Angeles, CA 90027, Tel.: +1 323361 8502, Fax: +1 3233618599 , galdrovandi@chla.usc.edu.

The authors have no conflicts of interest to declare. 


\section{Inefficiency of HIV transmission}

The majority of pediatric HIV infection occurs via mother-to-child transmission (MTCT) at three distinct time points: in utero, intrapartum, or through breast milk. In chronically HIVinfected women not receiving antiretroviral therapy (ART), transmission rates are approximately $5-10 \%, 10-20 \%$, and 5-15\%, respectively (1). Maternal levels of HIV are a major risk factor in all forms of transmission, while a rare polymorphism in the chemokine receptor CCR5 is the most protective. Nevertheless, most children born to women with high levels of HIV and low numbers of $\mathrm{CD}^{+}{ }^{+} \mathrm{T}$ cells do not become infected. Even when primary HIV infection occurs during pregnancy and levels of viremia are extremely high, $80 \%$ of children escape infection (2). In addition, some children elude in utero and intrapartum infection but later acquire HIV through breastfeeding. These observations suggest that other phenomena modify the interplay between maternal infectiousness and infant susceptibility. Biologic, behavioral, and environmental factors associated with transmission are summarized in Table 1. Despite decades of research, the role of immunity versus viral exposure (quantity and quality) in transmission remains elusive and controversial (3). Below we briefly review the biology of MTCT.

\section{In utero transmission}

Transplacental HIV transmission is the least efficient form of MTCT. Despite 9 months of exposure at the maternofetal interface and evidence of bi-directional cellular trafficking between mother and fetus, only $5-10 \%$ of children become infected $(4,5)$. Variable but persistent levels of maternal cells can be detected in healthy children, suggesting that significant numbers of infants are exposed to HIV-1 in utero. Indeed, maternal cells can be detected in the blood of HIV-uninfected infants born to HIV-infected women $(5,6)$. Why then are most fetuses not infected?

A compelling hypothesis is that the developmentally regulated propensity of fetal cells to avoid inflammatory responses thwarts infection. Most fetal cells are quiescent, while efficient productive HIV infection only occurs in activated T cells (7). The fetomaternal cellular exchanges that potentially transmit HIV also promote the development of fetal Tregulatory cells (Tregs). These Treg cells actively suppress immune responses to maternal antigens (8). In utero exposure to foreign antigens, e.g. placental malarial infection, has been associated with increased Treg cell populations at birth (9). The observation that in vitro depletion of Treg cells in HIV-1-exposed uninfected infants increases the detection of HIVspecific responses is consistent with this hypothesis (10). Further support is provided by studies demonstrating the strong associations between in utero transmission and placental inflammation (11-14).

Although immune quiescence is an attractive hypothesis, the human fetal intestine is populated with the natural targets of HIV infection $\left(\mathrm{CD} 4{ }^{+} \mathrm{CCR} 5^{+} \mathrm{T}\right.$ cells), and in vitro, these cells are susceptible to HIV infection (15). Additionally, ex vivo fetal enterocytes have a marked inflammatory propensity when stimulated and this persists until term (see below). In fact, fetal tissues and cells are more permissive to HIV infection compared to adult cells and tissues (16-19). This observation raises the possibility that additional amniotic and/or placental factors quell fetal inflammatory intestinal responses in utero. Innate and adaptive placental cellular responses with immunomodulatory and/or antiviral properties have been described (20-24), and whether these or other factors play a role is uncertain.

\section{Intrapartum transmission}

In the absence of antiretroviral (ARV) prophylaxis, the majority of HIV-transmission occurs at the time of delivery. Whether this is due to transplacental transfer of virus during 
parturition or infant exposure to maternal secretions and blood at delivery is uncertain. However, the protective effect of cesarean section (25) coupled with the presence of both $\mathrm{HIV}$ in infant gastric aspirates (26) and $\mathrm{CD} 4^{+} \mathrm{CCR} 5^{+} \mathrm{T}$ cells in the neonatal gut (15) suggest most intrapartum transmission is likely mucosal. Additionally, the inflammatory cytokines and chemokines present in placentas of mothers who transmit in utero are not seen in the placentas of mothers who transmit during delivery, suggesting a different mechanism of transmission that is unlikely to be transplacental (11). Factors that increase the risk of likelihood of intrapartum transmission are listed in Table 1.

A unique feature of pediatric transmission is that it generally occurs in the presence of HIVspecific antibody. During the third trimester of gestation, maternal immunoglobulin G (IgG) antibodies are transplacentally transferred, such that at term, infant levels are equivalent to or higher than those in the maternal circulation (27). These antibodies are associated with infant protection against a variety of microbes (28). Although maternal antibodies have been associated with inhibition of infant immune responses, this suppressive effect is highly variable and does not preclude the generation of T-cell responses and/or priming (29). A key remaining question is whether maternal antibodies (neutralizing and/or non-neutralizing) modify transmission risk and/or disease progression in HIV-infected infants. Studies on the role of maternal antibodies in MTCT are inconsistent, but in simian immunodeficiency virus (SIV) models, broadly neutralizing antibodies can prevent infection (30-34) and modify immunity in infected neonatal macaques (32). These studies provide proof of principle for the use of broad-neutralizing monoclonal antibodies in preventing MTCT in high-risk infants.

\section{Breast milk transmission}

Fewer than one in five infants become infected via breast milk, even though the immune system is not yet 'fully mature' and the infants are exposed up to every 2 hours for months to years (estimates include exposure to $>60,000$ infected cells and 500,000 cell-free virions daily) (35). Breast milk HIV-1 transmission, like sexual transmission, depends on (i) breaching an epithelial barrier that limits the amount of HIV in the transmitting fluid, (ii) remaining in an infectious form within the secretion, and (iii) traversing another mucosal surface to infect a new host.

The mammary epithelium is very effective in curtailing HIV entry into breast milk and most likely represents an important mechanism by which infant transmission is restricted. HIV RNA levels in breast milk are at least 100-fold lower than those in the circulation (36). In the absence of ART, approximately a third of HIV-infected women have breast milk HIV RNA levels below 50 copies $/ \mathrm{ml}$, while another third shed virus only intermittently (37). Breast milk viral shedding is increased by conditions associated with increased mammary epithelial permeability including parity, sudden changes in the frequency of breastfeeding, mastitis and abscess (38) with a concomitant increase in transmission $(39,40)$. However, even in the setting of a breast abscess, breast milk HIV levels remain significantly below levels in the bloodstream (41). Interestingly, this viral restriction is quantitative not qualitative. The HIV variants that enter breast milk are genetically indistinguishable from those in contemporaneous plasma $(36,42-44)$. Within breast milk there is limited viral evolution, which may reflect restricted replication $(36,43,45)$. This is a surprising finding given the marked immunologic differences between the breast milk and blood (46) but suggests that the genetic bottleneck observed during transmission does not occur in breast milk. The factors governing viral restriction are incompletely understood; however, there is increasing evidence demonstrating that epithelial cells have dynamic and reciprocal interactions with adaptive and innate immune factors (47). 
Breastfeeding behavior also plays an important role in transmission risk. Exclusive breastfeeding reduces HIV breast milk transmission by more than $50 \%$ compared to mixed feeding, i.e. feeding infants water, other liquids, and/or solids in addition to breast milk (48). This observation seems counterintuitive as exclusively breastfed infants have greater HIV exposure, yet the findings are reproduced in several large studies including two set out specifically to examine this hypothesis (49-53). Although it has long been recognized that exclusive breastfeeding is associated with decreased morbidity and mortality in non-HIV infected populations (54-56), why this simple behavior would so consistently and dramatically prevent HIV infection remains a 'milk mystery'. Two non-mutually exclusive mechanisms have been proposed. The first is that mixed feeding disrupts the gastrointestinal epithelium by (i) introducing dietary antigens and/or pathogens, (ii) decreasing the exposure to the bioactive molecules in milk that promote intestinal integrity, decrease inflammation, and provide anti-microbial protection, and/or (iii) displacing or altering commensal microbial communities. The second potential mechanism is that non-exclusive breastfeeding disrupts mammary epithelia integrity. Women produce milk at a rate largely dictated by infant suckling. Interruptions and/or displacements of infant feeding disrupt the natural homeostasis reached between milk production and milk ejection in the mother-infant pair. This disruption leads to milk stasis and breast engorgement with subsequent increases in mammary epithelial tight junctions. If milk is not ejected, epithelial permeability increases, allowing the bidirectional passage of substances between the milk ducts and the circulation and produces a local and systemic inflammatory response (mastitis). Non-exclusive breastfeeding is associated with breast pathology, whereas exclusive breastfeeding reduces mastitis and breast abscess, both of which are associated with increased viral load (57). Whether the increase in transmission with non-exclusive breastfeeding is due to changes in breast milk viral load, the inflammatory response that accompanies changes in mammary epithelial integrity, the interruption of the constant immune modulation provided by breast milk, or the increase in foreign antigens as the infant gut is exposed to formula or a combination of these factors is unknown (57-61).

Breast milk contains a rich array of factors that could potentially facilitate or hinder HIV transmission either directly or indirectly (Table 2). To date, most studies have been limited by small sample size and a focus on a single or a few factors while protection is likely multifactorial and may differ between cell free and cell-associated virus (62). Another confounding factor is that the composition of milk is highly variable between women and over time. Given the evolving nature of the suckling child's oral mucosa, intestinal tract and immune system, protection may be mediated by different factors at different times. Not surprisingly, high concentrations of pro-inflammatory molecules [e.g. CXCL12, CCL5 IL-8, RANTES, IL-8, IL-15, macrophage inflammatory protein 1a (MIP-1a)] have been associated with increased risk of transmission in most but not all studies, while low levels of breast milk IL-7 correlated with transmission in one study (63-69). Other breast milk components with protection in clinical studies include a-defensins (70, 71), long-chain n-6 polyunsaturated fatty acids (72), non $3^{\prime}$-sialyllactose ( $3^{\prime}$ SL) human milk oligosaccharides (73), and erythropoietin (74). Although breast milk HIV-specific IgA was not associated with transmission (75), HIV-specific antibodies capable of antibody-dependent cell cytotoxicity (ADCC) were found to be protective in one study (76). Breast milk substances that interfere with HIV binding and infection in vitro include Lewis $\times$ factor, bile salt lipase, oligosaccharides, soluble Toll-like receptor 2, glycans, MUC1, and lactic acid bacteria (66, $67,77-81)$.

Unlike other secretions, breast milk has a relatively high concentration of immune cells, including antigen-specific $\mathrm{T}$ cells directed towards pathogens unlikely to infect the breast, e.g. influenza and respiratory syncytial virus. This suggests that these cells play a role in infant protection either at mucosal surfaces or systemically (82-84). In rodents, these cells 
home to the lactating gland from the maternal intestine and respiratory tract. In humans, these cells are phenotypically distinct from those in the blood (85-87). In animal studies, these cells can traverse the gastrointestinal tract and are functional in the suckling animal but human data are sparse and controversial (88-93). The role of breast milk immune cells in HIV transmission is unclear. HIV-specific $\mathrm{CD}^{+} \mathrm{T}$ cells are enriched in the breast milk of HIV-infected women but do not correlate with HIV RNA levels in milk $(84,94)$; however, one study found an association with HIV-specific responses and peripartum HIV transmission (65). Activated HIV-specific breast milk B cells have also been described, but their role in transmission is unclear (95).

The most consistent predictors of HIV breast milk transmission are levels of HIV, breast pathology (inflammation), and non-exclusive breastfeeding. The mammary epithelium plays a very important role in curbing HIV transmission. A pot pourri of factors within breast milk have been associated with transmission risk, but the effects and sample size have been modest. Nevertheless, these factors alone or in combination appear to restrict HIV replication within breast milk and/or transmission. Comprehensive strategies and large sample sizes are needed to tease out which of these factors may confer protection from HIV.

\section{Clinical course of pediatric HIV}

Most in utero infections occur a few weeks prior to delivery (96), and the disease course in these infants is strikingly different from infants infected at the time of birth with a median survival time of 208 versus 380 days (97). Infants delivered prior to 34 weeks of gestation are twice as likely to become infected intrapartum or through breast milk than infants born after 37 weeks of gestation (term) (98). Infants infected peripartum are more than three times more likely to die 180 days post-infection than infants infected via breast milk (99) (Fig. 1). HIV-infected infants who switch to formula at 4 months of age rather than continue breastfeeding through 16 months die at a median of 8 months versus 17 months (40) (Fig. 2 ). These profound differences highlight the importance of timing and potentially the route of infection on both acquisition of infection and disease progression. Unfortunately, the biologic basis of these differences remains speculative.

The evolution of HIV infection in adults is slow with a 10- year median progression to AIDS or death. In the weeks following acute infection, plasma viremia decreases by 100 to 1,000 -fold and is relatively stable at this 'viral load set-point' for many years. The plasma HIV RNA level and the absolute CD4 ${ }^{+} \mathrm{T}$-cell count at this set-point are independent predictors of disease progression. In contrast, during the first few months post-infection, infant plasma viremia generally increases 10 -fold to levels that are much higher than those in adults $(100,101)$. Most untreated infants have plasma HIV RNA levels of $>100,000$ per $\mathrm{ml}$, and levels of a million or greater per $\mathrm{ml}$ are not uncommon. In children, HIV RNA levels slowly decline and do not reach a set-point until around age 5 years (102)(Fig. 3).

Rates of clinical disease progression differ markedly between children and adults. Initial reports suggested there was a bimodal distribution: about $20-30 \%$ of children experienced rapid progression to AIDS or death in the first year of life, and the remainder of children deteriorated at rates similar to adults. However, this description oversimplifies the complexity of HIV infection in children. An analysis of almost 4,000 perinatally infected children revealed striking age-related differences in disease progression in children less than 5 years of age (103). Regardless of the level of $\mathrm{CD}^{+} \mathrm{T}$ cells or plasma viremia, younger children are at greater risk of death or progression to AIDS compared to their older counterparts (Fig. 4). A 1-year-old child with $10 \% \mathrm{CD}^{+} \mathrm{T}$ cells has a $40 \%$ risk of progression to AIDS and $20 \%$ risk of death within 12 months. The risk for a 10 -year-old with those same laboratory values is $7.4 \%$ for developing AIDS and $2.1 \%$ for dying within 
12 months. The risk of progression to AIDS or death in a 1-year-old child with a plasma RNA level of 100,000 copies per $\mathrm{ml}$ is $11 \%$ and $5 \%$ respectively, but a 10 -year-old's risk is $5.1 \%$ and $2 \%$ respectively. After age 5 years, the risk of disease progression and death and the predictive value of $\mathrm{CD}^{+} \mathrm{T}$-cell and plasma RNA levels appear to be similar to those observed in young adults (103).

The reasons for these striking differences are unknown but are usually attributed to immunologic 'immaturity' and the rapid expansion of $\mathrm{CD} 4{ }^{+} \mathrm{T}$ cells that accompany somatic growth (see below). Other factors that have been suggested to contribute to the high level of viremia in young children include an increased susceptibility of infant cells to HIV-1 infection (104) and shared HLA alleles between mother and child, so that the virus is preselected for fitness in the infant $(105,106)$. Notably, children infected with HIV-1 during adolescence tend to fare better than adults (107) (Fig. 5).

\section{Infant exposure occurs during immunological development}

\section{Normal development of the human immune system (Table 3)}

Infants and young children are more susceptible to infection and have suboptimal responses to many vaccines. Recent studies suggest that differences between infant and adult immune responses are not due to an infant's inability to respond ('a baby immune system') but rather reflect age-specific patterns of response (28). In other words, infants are not incapable of responding to stimuli. Instead, their responses are qualitatively and quantitatively different. The infant emerges from a sterile environment where an untoward inflammatory response can lead to premature birth and/or death. In utero, the infant must actively tolerate self and her/his mother (108). Once born, the infant is assaulted by antigens and pathogens and must immediately learn how and when to respond. The transition from a bias towards tolerance to an effector or priming response occurs over several years. During these early vulnerable years the infant relies on maternal protection and 'instruction'. Mothers provide transplacental antibodies, the microbes that initially colonize the infant and breast milk. Breast milk contains thousands of immunomodulatory molecules that stimulate growth and guide the child's immune development such that dietary and non-invasive antigens are tolerated while pathogenic antigens are dispatched. This complex and dynamic fluid is synchronized with the infant's needs and provides important defenses against infection. These early maternal influences have profound life-long effects on the immune responses and propensity to develop disease. Although differences between adult and pediatric immunity are most striking in young children, full immune competence is not achieved until adolescence, and maturation is asynchronous between immune components. The major differences in pediatric and adult immunity are briefly reviewed and discussed in the context of HIV infection.

Compared to mice, humans are born with a relatively mature immune system. T cells populate the peripheral lymphoid tissues as early as 10 gestational weeks (109), and B lymphocytes and antigen-presenting cells (APCs) can be detected by the end of the first trimester of gestation (110). Generally neonatal immune cells including APCs (dendritic cells, monoctyes, and macrophages) do not respond to costimulation in the same manner as adult cells and possess a greater capacity to produce the anti-inflammatory cytokine interleukin-10 (IL-10), contributing to an immunologically permissive environment (108). The expression and function of Toll-like receptors (TLRs) are developmentally regulated and responses are modified by soluble circulating factors (111-116). In response to TLR stimulation, including lipopolysaccharide (LPS), infant cells produce lower levels of cytokines that support T-helper 1 (Th1) cell differentiation (IFN- $\gamma$ and IL-12) and higher levels of cytokines that support Th17 cell differentiation (IL-6, IL-23 and IL-1beta) (115118). These responses promote a tolerogenic immunologic milieu with a distinct Th2 and 
Th17 bias. These propensities are due to distinct epigenetic profiles and processes as well as the differential expression of microRNAs regulating transcription of cytokine genes in fetal/ neonatal cells compared to adult cells (119-121).

Adaptive immune responses are also highly age-dependent (122). The majority of neonatal $\mathrm{T}$ cells are naïve and exhibit diminished proliferative responses, and lower IL- 2 and IFN- $\gamma$ secretion. Many of these cells are recent thymic emigrants (RTE), which are hyperresponsive to IL-7 and relatively resistant to acquiring Th1 function (123). Maternal cells crossing the placenta induce Tregs. The Treg cells express the forkhead box p3 (Foxp3) transcription factor and constitute up to $15 \%$ of the $\mathrm{CD} 4^{+} \mathrm{T}$ cells during fetal life and then decrease in the circulation(8). Most infant Tregs express the intestinal homing receptor $\alpha_{4} \beta_{7}$ and display preferential migration to the intestine (124). In contrast to other fetal and infant immune cells, the functional abilities of fetal/neonatal Tregs are equivalent to those observed in adults (125). Treg cells have a reciprocal relationship with Th17 cells and the balance between these two $\mathrm{CD}^{+}{ }^{+} \mathrm{CD} 4^{+} \mathrm{T}$-cell subsets is believed to be critical for dictating pro- versus anti-inflammatory responses. In mice, mucosal Th17 cells depend on intestinal colonization with specific bacteria (126-129); however, the role of bacteria in human Th17 development is unknown. Human fetal intestines contain large numbers of Th17 cells (130), but the relative composition of Th17 and Treg in human infants and how this balance varies during development is unknown. Murine studies indicate that Treg cells, particularly those in the intestine are a heterogeneous population (131), that display tremendous functional plasticity especially under lymphopenic and inflammatory conditions (132). Studies of peripheral blood Th17 $\mathrm{CD} 4^{+}$cells indicate this cell population is developmentally regulated and inversely related to age (133). Neonatal $\mathrm{CD}^{+}{ }^{+} \mathrm{T}$ cells also have reduced expression of CD40L and provide less help for B-cell function. Naive infant B cells express lower levels of CD21, CD40, CD80, CD86, and typically neonatal antibody responses are delayed in onset, achieve lower peak levels, and persist for a shorter period of time (134). Qualitatively these antibodies have less affinity maturation, heterogeneity, and differ in the distribution of IgG isotype (lower titers of IgG2) compared to adults (134).

In addition to these qualitative differences, there are marked age-related differences in the number of immune cells (Fig. 6). The absolute number and relative percentage of circulating $\mathrm{CD}^{+} \mathrm{T}$ cells are much higher in infants and children $(135,136)$. Immediately after birth levels increase, peaking in the first few months of life at 3-4 times adult values and then slowly decline, reaching adult levels at around age 6 years (135) (Fig. 3). There is less variation in the number of $\mathrm{CD} 8^{+} \mathrm{T}$ cells. Relative to their body size, the mass of the thymus is increased and thymopoiesis is much more active during childhood and begins involution after puberty (137).

Levels of transplacental maternal antibodies decrease over the first few months of life as infant B-cell responses mature (138) (Fig. 7). However, even after one year of age, Ig levels, particularly $\operatorname{IgA}$, remain well below those in adults. $\operatorname{IgG}$ subclass production also matures slowly reaching $60 \%$ of adult levels for $\mathrm{IgG} 1$ and $\mathrm{IgG} 3$ at one year of age and $\mathrm{IgG} 2$ and IgG4 at 2 to 5 years of age. B-cell function remains distinct from that observed in adults throughout childhood (134). By 2 months of age, infants respond well to protein antigens; however, response to polysaccharide antigens does not develop until approximately 2 years of age. The size and number of lymph node germinal centers is also decreased and in mice maturation of follicular dendritic cells is delayed (139). The ontogeny of B-cell responses is influenced not only by limited T-cell stimulation but increasing evidence suggests that the intestinal microbiota plays an important role (140) (see below). Interestingly, the administration of Ig to infants (even premature infants) does not decrease their risk of infection, as has been observed with patients who have Ig deficiencies. This observation underscores the complexity of immune development and the interplay between factors that 
renders infants susceptible to severe infections. Beyond Ig, infant complement levels, opsonophagocytic activity, and granulocyte reserves are substantially lower when compared to older children and adults (141).

Despite an innate bias against Th1 responses, when presented with certain antigens, infants can respond robustly and appropriately. For example, bacillus Calmette-Guerin (BCG) immunization elicits a Th1-type response in newborns of similar magnitude to that achieved later in life (142). Similarly, in utero cytomegalovirus (CMV) or Trypanosoma cruzi infection is associated with mature functional CD8 ${ }^{+} \mathrm{T}$-cell responses $(143,144)$. Antibodyspecific B lymphocytes can be primed in utero; however, antibody responses to protein antigen, and particularly polysaccharide antigens, are weaker in infants than in adults (134). In sum, the constellation of neonatal responses primarily protects against extracellular bacterial pathogens $(145,146)$ rather than intracellular bacteria or viruses. Eventually, over early childhood there is a gradual increase in responses that combat intracellular pathogens and viruses (146). However, under certain conditions infant can overcome their 'bias'. The biologic basis of why infants develop 'mature' responses to some antigens and not other (timing of exposure, route, dose, and type of antigen, activation of APC, etc.) remain elusive.

\section{Gastrointestinal development}

The architecture of the intestinal mucosa is established early in human fetal life, and the gutassociated lymphoid tissue (GALT) generally develops in parallel with other lymphoid organs (147) (Fig. 8). However, it is only in the last few weeks of gestation that lymphoid components begin to assume the organizational structures that facilitate appropriate interactions and cross-talk. The development of germinal centers in the Peyer's patches, IgA plasma cells in the lamina propria, and the dominance of $\mathrm{CD} 8^{+}$intraepithelial cells occurs late in the third trimester and continues in the post-natal period (147). Studies of CD8knockout mice suggest these cells are crucial for the downregulation of enterically elicited mucosal immunity (148). Marked changes in the expression of innate immune response genes on enterocytes also occur late in gestation. Studies of fetal, premature, and term infant intestines have revealed developmental downregulation of TLR cell surface expression and associated signaling molecules and upregulation of negative regulators shortly before birth $(149,150)$. These developmentally regulated changes appear to contribute to the propensity of the immature intestine to respond to stimuli with an excessive inflammatory response (149). Clinically, this response is manifested as necrotizing enterocolitis (NEC). NEC is a severe form of enteritis observed almost exclusively in premature infants and very rarely in term infants. Although the pathogenesis of this disease is complex, the interplay between an immature exaggerated response to stimuli and the process of bacterial colonization is believed to be central to its development (151).

At birth, the infant intestine begins its two critical functions: nutrient assimilation and maintaining immune homeostasis while being challenged with an extraordinary number of antigens. To deal with the antigenic onslaught, two general mechanisms have evolved. The first prevents these antigens from penetrating the mucosal barrier and is accomplished by physical means (e.g. tight junctions, mucin, epithelial receptors), secretory antibodies (IgA and $\operatorname{IgM}$ ), and various non-specific innate factors. The second mechanism involves limiting the immune response to innocuous environmental and dietary antigens by means of suppressing proinflammatory responses. The newborn must meet these challenges with a permissive mucosal barrier and a naive immune system that must learn to distinguish 'friend from foe'. Thus, immune homeostasis is the balance between epithelial 'leakiness' and suppressing immune responses. The major stimuli influencing postnatal development of mucosal immune homeostasis appear to be the establishment of intestinal microbiota and the timing and dose of dietary antigens (152). 
The infant gut is immediately seeded with bacteria, and these initial bacterial encounters appear to have long-lasting immunologic and metabolic effects (153-155). For example, infants born via cesarean section harbor distinct bacteria from those delivered vaginally (156) and have delayed intestinal colonization by Lactobacilli, Bifidobacteria, Bacteroides, and other bacteria $(157,158)$. These differences may account for the increased incidence of asthma and inflammatory bowel disease in children born by cesarean section (159). Microbial colonization is a complex and dynamic process, and an adult microbial community structure is not established until around 2 to 3 years of age (160). Major factors influencing the infant gut microbiota appear to be genetics, mode of delivery, diet, and exposure to antibiotics $(161,162)$. The seeding of the infant intestine is facilitated by low gastric acid and pancreatic enzyme production, which allows pathogens including HIV access to the intestinal mucosa (26). The overlying mucin and epithelial receptors on neonatal enterocytes have a distinct glycosylation pattern that changes over time especially during weaning and are believed to be important for guiding microbial succession.

\section{Role of microbiota in intestinal development}

Bacteria play a central role in the establishment and regulation of epithelial barrier function as well as GALT maturation in both mice and humans. Over the first few months of life, rudimentary infant Peyer's patches become seeded with IgM and IgA and plasma cells and germinal centers develop. Adult numbers of Peyer's patches are not attained until adolescence (163). Early infant colonization with Bacteroides fragilis has been associated with maturation of humoral responses $(164,165)$, and in murine models, this organism promotes Treg cell development and decreases inflammation (166). By 6 months of life, the infant gut has undergone marked structural and biochemical changes as well as major shifts in the microbiota, enabling it to digest foods other than breast milk or formula.

The role of breastfeeding in shaping the composition of infant stool has been appreciated since the early $20^{\text {th }}$ Century and today is being refined with culture-independent techniques. Not only does the stool bacterial composition differ between breast-fed and formula-fed infants, the expression of immunity-related genes in intestinal epithelial cells also differs (167). The factors in milk that contribute to these differences are an active area of investigation but likely will be numerous and multifaceted. Unlike formula, breast milk is not sterile. It contains hundreds of bacteria (e.g. Lactobacilli, Bifidobacteria) that appear to traffic to the mammary gland from the maternal intestine $(168,169)$. Breast milk also contains thousands of bioactive molecules including immunocompetent cells, antibodies, lysozyme, lactoferrin, fatty acids, antimicrobial peptides and glycopeptides, which can inactivate pathogens individually, additively, or synergistically (170). Bacterial colonization is also shaped by the presence of hundreds of unique human milk oligosaccharides (HMOs). HMOs are the third largest constituent of milk and require approximately $10 \%$ of the maternal caloric intake for milk production. Such a large expenditure of energy may seem to be an evolutionary folly since the infant cannot digest HMOs. However, it is now appreciated that this complex mixture nourishes the commensal bacteria prevalent in the feces of breastfed infants (171). In addition, HMOs modulate intestinal epithelial receptors, microbe attachment, and cellular responses to stimuli (172).

The stools of breastfed infants are enriched with bacteria that decrease intestinal inflammatory responses, including innate immune mediated inflammation and influence the balance between Treg and Th17 cells (173). These bacteria, along with other factors in breast milk, promote intestinal homeostasis and decrease inflammation. The use of breast milk has transformed the treatment of NEC, and studies using probiotic bacteria in milk are being used in clinical trials (174). Breast milk decreases the risk of developing NEC by 58 to $83 \%$, and even partial breastfeeding provides a significant benefit (175). These effects are consistent with studies observing less intestinal inflammation in breastfed children infected 
with enteric pathogens compared to those fed formula $(176,177)$. Breast milk also suppresses the inflammatory response to stimuli when fed to rodents or added to enterocytes in vitro, but which factors or combination of factors are responsible is uncertain (178). Nevertheless, the infant microbiota is inextricably linked to breast milk.

\section{Breast milk and the ontogeny of infant immunity}

Breast milk contains a cornucopia of factors that promote intestinal epithelial integrity, growth, and maturation. Intestinal permeability is high at birth and decreases progressively during the first week of life. However, intestinal barrier function does not fully mature until age 2 years (179). This relatively leaky gut is believed to promote tolerance by allowing low dose continuous exposure to antigens. Intestinal maturation and epithelial barrier function are greater in breastfed infants, probably due to the presence of trophic factors including epidermal growth factor, insulin-like growth factor, nucleotides, and other substances (180). Despite these leaky guts, infants and young children have no evidence of systemic immune activation. In fact, their cells are remarkably quiescent. In mice, small transient breaches in the intestine produce dominant regulatory T-cell responses that protect the mucosa from inflammation (181). It is possible that the physiologic anatomical leakiness of childhood results in similar responses.

Although breast milk is often viewed simply as 'food', lactation first evolved as a protective immune secretion, and only later in our evolutionary history did it assume a nutritional role (182-184). The mammary gland is arguably the most important part of the integrated mucosal immune system, since it ensures the survival of infants and represents 'immunologic integration between mother and child' (185). Even in countries with access to antibiotics, vaccines, medical care, and clean water, breastfeeding is associated with a 50\% reduction in hospitalization for diarrhea and 30\% reduction for respiratory disease (186). The protective effects of breastfeeding are dose dependent and greatest when infants receive exclusive breastfeeding for the first 6 months of life and then continue to breastfeed until 2 years of age (187).

Given its evolutionary importance, it is not surprising that breast milk appears to compensate for infant immune deficits (188). For example, at birth newborns lack secretory IgA (sIgA), and IgA-producing plasma cells do not appear for several weeks. Breast milk both accelerates the development of IgA-producing plasma cells and supplies large quantities of sIgA with specificities that reflect maternal microbe exposure (189). Pathogenspecific sIgA directly influences intestinal colonization. Additionally, sIgA inhibits macrophage release of proinflammatory cytokines and plays an important role in intestinal epithelial cross-talk, the balance between Treg and Th17 cells (190). sIgA is known to resist digestion, but the unique physiology of the infant gastrointestinal tract coupled with the buffering ability of breast milk appears to permit delivery of other functional molecules to the infant (191). Breast milk IL-7 concentrations are 100-fold higher than maternal plasma levels, and both thymic size and immune responses to vaccines are reportedly increased in breastfed infants (192). Correlations of breast milk IL-7 concentrations with thymic size and signal-joint T-cell receptor-rearrangement excision circles (sjTRECs) in Gambian children (193) suggest that maternally derived IL-7 traverses the infant gut and is functionally active. Murine studies have demonstrated oral functional IL-7 transfer (194).

Breastfeeding during the introduction of complementary foods is important for the development of oral tolerance (195). Breast milk contains an extraordinary number of factors that modulate both the adaptive and innate immune systems (188) (Table 2). Many of these bioactive molecules (e.g. soluble TGF- $\beta$, IL-10, anti-oxidants, anti-proteases, cytokines, and fatty acids) are anti-inflammatory and are believed to play an important role in oral tolerance $(196,197)$. The high levels of IL-7 and IL-15 in milk may contribute to 
more robust responses to vaccines observed in some studies comparing breastfed and formula-fed infants (187). Compelling but incomplete evidence indicates that breastfeeding has long-lasting immune effects, including the prevention of allergic and inflammatory diseases (198-202). Thus, breast milk shapes the development of the infant gut as a mucosal barrier, an immune organ, and a site of mucosal immune homeostasis. Breast milk promotes this development by providing immune protection, immune 'guidance', and nutrition (for both the microbes and the infant) in a complex, integrated, and coordinated way that only Mother Nature can accomplish. Any imbalance of this developmental process is likely to have devastating effects.

\section{Effects of HIV on the developing immune system}

In the absence of ART, HIV-infected children die at alarming rates. The timing of infection is critical with striking differences in survival between children infected in utero, intrapartum, and by breastfeeding (Fig. 1). Additionally, children born to HIV-infected woman who escape infection (HEU-HIV-exposed uninfected) do not escape harm. Thus, HIV has a profound impact on infected children and intriguingly appears to do harm to children born to HIV-infected women that escape HIV infection. The mechanisms by which HIV impacts the developmental changes in infant immunity and how this in turn impacts the natural history of HIV are poorly understood. Below, we review and discuss available data.

Why do infants infected at 34 weeks gestation, birth (37 weeks gestation), or 3 months of age have such markedly different fates? Early studies focused on the quantity and quality of cellular immune responses to HIV, and not surprisingly, infant immune responses were inadequate. HIV-specific CD ${ }^{+}{ }^{-}$-cell responses are detected only sporadically in perinatally infected infants less than 3 months of age (203) and remain low or undetectable even when ART has been initiated in the first weeks of life (204). HIV-specific CD8 ${ }^{+} \mathrm{T}$-cell responses can be detected at birth in infants infected in utero but are functionally ineffective (205, 206). In fact, functional $\mathrm{CD} 8^{+} \mathrm{T}$-cell responses are not vigorously detected until 3 years of age and only in subjects who have maintained substantial CD4+ T cells (207). Since HIVspecific $\mathrm{CD}^{+}{ }^{+} \mathrm{T}$-cell responses are critical for the induction and maintenance of both effective $\mathrm{CD}^{+} \mathrm{T}$-cell responses and B-cell activity, the lack of $\mathrm{CD} 4^{+} \mathrm{T}$-cell responses may be one explanation for these findings. Active production of HIV-specific ADCC antibodies is observed in the majority of HIV-infected infants only after 12 months of age (208). A decreased capacity of neonatal natural killer cells to mediate ADCC $(209,210)$ may also contribute to the lack of viremic control. Ineffective immune responses coupled with the large number of $\mathrm{CD}^{+} \mathrm{T}$ cells, furnished by an active thymus, undoubtedly contribute to the high viral loads and the rapid disease progression observed in children. However, these factors are insufficient to fully explain the profound survival differences observed over only a few weeks time.

Until recently, there was limited information on the distribution of HIV target cells in infants. The overwhelming majority of transmitted viruses use the CCR5 co-receptor and productive HIV infection requires activated $\mathrm{CD} 4^{+} \mathrm{T}$ cells. The majority of infant cells are quiescent, and infants have a remarkable absence of $\mathrm{CD}^{+}{ }^{+} \mathrm{CRR} 5^{+} \mathrm{T}$ cells in cord blood and only a few in lymph nodes $(15,211)$. Furthermore, levels of $\mathrm{CD} 4^{+} \mathrm{CCR} 5^{+}$expression on peripheral $\mathrm{T}$ cells do not achieve adult levels until age 5 years, even in children living in resource-poor settings $(211,212)$. So, the question remained as to where the target cells of infant infection were located. A recent study of fetal and neonatal intestines found an abundance of memory $\mathrm{CD}^{+}{ }^{+} \mathrm{CCR} 5^{+} \mathrm{T}$ cells with predominantly $\mathrm{Th} 1$ and $\mathrm{Th} 17$ phenotypes localized in gut epithelial cells and lymphoid aggregates of the gut submucosa (15). These memory $\mathrm{CD}^{+} \mathrm{CCR}^{+} \mathrm{T}$ cells were highly susceptible to $\mathrm{HIV}$-infection in vitro without prior activation and are likely a prime site of HIV infection, replication, and destruction in infants 
and children. Since destruction of $\mathrm{CD} 4^{+} \mathrm{T}$ cells residing in the gastrointestinal tract is a critical early event in HIV-1 pathogenesis in adults (213-216), and most of the depleted gut $\mathrm{CD}^{+} \mathrm{T}$ cells belong to the Th17 subset $(130,217,218)$, it is likely that the gut is an important site of viral replication and destruction in infants as well. There are no human studies of changes in the intestinal tract of HIV-infected infants; however, studies of SIV infection of infant macaques show a rapid, profound, and selective depletion of intestinal $\mathrm{CD}^{+} \mathrm{T}$ cells (219). Rates of $\mathrm{CD} 4^{+} \mathrm{T}$-cell turnover and proliferation are much higher in infant compared to adult macaques and may lead to more rapid exhaustion of finite precursor T-cell pools (220). The large $\mathrm{CD}^{+} \mathrm{T}$-cell pool has been suggested as a mechanism of age-related differences in viral loads and disease progression (220). However, this model most likely oversimplifies the complexity of homeostatic mechanisms deranged by HIV infection. As discussed above, ontogeny of Th17 and Treg subsets in the infant gut are undefined, but the aberrations introduced by HIV infection during this critical developmental window are most likely profound and long-lasting.

\section{In utero versus intrapartum HIV infection}

Changes during fetal and neonatal intestinal development may explain the survival differences associated with the timing of HIV infection (median survival 208 days in utero acquisition versus 380 days intrapartum acquisition). As discussed above, in response to antigenic stimulation, fetal and preterm intestines have an exaggerated immune response with massive production of IL-8 and other proinflammatory cytokines (221). We hypothesize that the responses of immature enterocytes act as an inflammatory accelerator in the setting of in utero HIV infection. The propensity of preterm cells to develop into Th17 cells and the relative paucity of mucosal $\mathrm{CD} 8^{+}$cells in the preterm intestine may also contribute. The net result is high levels of HIV replication and disruption of the regulatory mechanisms governing the epithelial barrier and nascent germinal center development. This disruption likely overwhelms the homeostatic mechanisms that govern Th1/Th2/Th17 intestinal balance, thus leading to even more infections and destruction. This devastation of critical developmental processes leaves an already vulnerable child defenseless.

Although term infants possess the same permissive T cells as the preterm infants, term enterocytes respond to stimuli in a qualitatively and quantitatively different manner. This developmental evolution is believed to be key in the pathogenesis of NEC and may also contribute to the survival advantage of intrapartum versus in utero infected infants. Nevertheless, the immunoregulatory networks at birth are fragile and a newborn's innate and adaptive immune responses are ill equipped to control viruses, let alone one like HIV (146). HIV's predilection for the intestine and $\mathrm{CD}^{+}{ }^{+} \mathrm{T}$ cells place the infected newborn at a distinct disadvantage. The newborn is immediately assaulted with billions of bacteria and other antigens. During this period, the newborn immune system must 'learn' to shift from a tolerant response to a priming response. In addition, the innate and adaptive arms of the immune system are learning to integrate and cooperate to maintain homeostasis. The gastrointestinal tract is the 'school' where the infant immune system learns many of these lessons and that education is undoubtedly disturbed by HIV infection.

As discussed above, mothers and their milk play a vital role in their children's immunologic development therefore it is probable that maternal HIV infection interferes with their ability to 'educate' their offspring. Understanding how maternal HIV influences infant development is crucial for the design of appropriate interventions. Whether HIV infection perturbs the maternal microbiota and how that might skew infant microbial succession is unknown. Differences in human milk oligosaccharide composition between HIV-infected and uninfected women suggest that there may be differences (73). At a minimum, HIV infection would be expected to impact the reciprocal nature of the regulation between the immune system and microbial community structures. Dysbiosis and alterations in the Th1/ 
Th2 balance have been associated with the development of allergic disease in HIV-negative children and this may account for the increased rates of asthma and atopy described in perinatally infected children $(222,223)$.

In adults, HIV infection has been associated with altered barrier function and microbial translocation. Although the role of microbial translocation in driving immune activation is controversial, there are fundamental differences in infant intestinal epithelial barrier function. Notably, intestinal leakiness is the physiologic norm, and this state is probably important for the development of immune tolerance. Presumably this is why infants are hyporesponsive to LPS (117). Although there are few studies in HIV-infected children, available data indicate that the effects of microbial translocation in young children are different from those observed in older individuals. A study of South African formula-fed infants detected circulating LPS in children less than 6 months regardless of HIV infection and LPS levels decreased to undetectable levels in all children at around 1 year of age (224). Although HIV-infected children less than 6 months had higher LPS levels than HIVnegative children, LPS levels did not differ between ARV-naive and ARV-treated children. Elevated LPS levels were also observed in healthy American children less than 2 years of age at levels similar to age matched HIV-infected children (225). However, in children over age 2 years, LPS concentrations were higher in HIV-infected children compared to agematched healthy controls. In this cohort, levels of LPS and soluble CD14 (sCD14) remained elevated in the HIV-infected children even after optimal viral suppression, CD4 cell recovery and resolution of lymphocyte activation. (225). In both the South African and US HIV-uninfected children, high levels of LPS were not associated with increases in other inflammatory markers. These data suggest marked age-related differences in responses to circulating microbial products.

\section{Postpartum HIV infection}

Compared to infants infected in utero and intrapartum, the infant infected by breast milk has the advantage of acquiring HIV in the context of a relatively more mature immune system and intestine. After 3 months of age, the ability of infants to successfully fight a variety of infections is markedly improved. By 4 to 6 months of age, the intestine has matured enough to ingest food antigens without eliciting an inflammatory response. Furthermore, as discussed above breast milk contains antimicrobial, anti-inflammatory and immunomodulatory agents that decrease the incidence of infection and accelerate somatic growth and immune development. Systemically and especially within the intestine, breast milk is associated with an anti-inflammatory environment, which would be predicted to attenuate HIV replication and its collateral damage. For these reasons, it is not surprising that rates of disease progression and death are much lower in breast milk-acquired HIV infection.

In Africa, some experts counseled mothers to stop breastfeeding their HIV-infected infants due to concerns of HIV super-infection and possible disease acceleration. However, two studies evaluating survival in breastfed HIV-infected infants show remarkably similar survival curves with a clear survival benefit in breastfed HIV-infected infants (40, 226) (Fig. 2). An Italian retrospective study in 1990 reported that the median progression to AIDS was 9.7 months for formula-fed children and 19.0 months for breastfed children ( $\mathrm{p}=0.003)$ (226). Survival from diagnosis was also significantly longer in the breastfed infants. The Zambia Exclusive Breastfeeding Study (ZEBS) was conducted over a decade later, but in both studies ART was not widely available to the study subjects. In ZEBS, women were randomized to a group instructed to stop breastfeeding at 4 months or a group instructed to continue breastfeeding for a duration of their own choice (40). All children were given cotrimoxazole prophylaxis, and those randomized to breastfeeding cessation were provided with formula and a nutritionally replete weaning cereal. There was no significant mortality 
difference in children with confirmed HIV infection prior to randomization. However, among HIV-infected children who were alive at 4 months, mortality rates by 24 months were $73.6 \%$ for children randomized to weaning compared to $54.8 \%$ in the control group who continued to breastfeed $(\mathrm{P}=0.007)$. Median survival was only 8 months in those randomized to breastfeeding cessation compared to 17 months $(\mathrm{p}=0.02)$ in those randomized to continue breastfeeding (40).

Although the survival benefit associated with breastfeeding for HIV-infected infants is extraordinary, these results echo the effects observed in HIV-negative populations (187). A protective benefit of breastfeeding has also been observed in HEU children (227-231). In ZEBS, HEU children randomized to stop breastfeeding had higher rates of morbidity and mortality compared to those randomized to continued breastfeeding (40). Multiple randomized trials (40, 232-235), historical controls (236-238), and epidemiologic studies (239-247) have shown increased morbidity and mortality of uninfected infants born to HIVinfected mothers when breastfeeding is curtailed, as recently reviewed elsewhere (248). Discontinuation of breastfeeding has adverse effects even when combined with safe water interventions (237). The causes of death among the HEU are those that claim the lives of children globally_-sepsis, pneumonia, and diarrhea. Presumably these are the pathogens that have plagued humans throughout history, so breast milk has evolved to provide protection. Defining the 'missing' components may provide clues as to how HIV disturbs mucosal immunity and the elements of maternal immunity that protect children from infection.

The protective effects of breastfeeding are less in HEU infants compared to infants whose mothers are HIV negative (249). Among HEU infants, the benefits of breastfeeding have been consistently associated with the severity of maternal disease, including in a large metaanalysis (250-253). HEU children whose mothers have lower CD4+ ${ }^{+}$-cell counts still derive significant benefits, although the benefits are of a smaller magnitude compared to women with higher $\mathrm{CD}^{+}{ }^{+} \mathrm{T}$-cell counts (234). Given the myriad of immunologic factors in breast milk, it is not surprising that the milk of severely immunodeficient women is not immunologically replete. To date, there have been few studies evaluating the immune 'competence' of HIV-infected women and its relation to child health. One study observed little to no differences in breast milk Ig concentrations (total and pathogen-specific) and innate immune factors [secretory leukocyte protease inhibitor (SLPI), lactoferrin and lysozyme], between HIV-positive and -negative women (254). Breast milk levels of CCL28 [also known as mucosae-associated epithelial chemokine (MEC)] were positively correlated with child survival in a small study (255).

Defining deficiencies in the breast milk of HIV-infected women could provide clues not only into how HIV deranges mucosal immunity but also reveal key immune factors that mediate protection against infectious diseases. Breastfeeding is considered the pillar of child health, but the complexity of mechanisms by which breast milk promotes child survival hampers our understanding. The immunologic derangements caused by maternal HIV infection may reveal the biologic basis of this protection.

\section{Uninfected but not unaffected: HIV exposed uninfected infants}

With the success of programs to prevent MTCT, there is a growing population of HEU children. Despite their escape from HIV-infection, there is an increasing body of evidence that these children suffer immunologic harm both with and without exposure to ARVs (256, 257) and independent of the effects of breast milk. In resource-poor countries, HEU children have significantly increased morbidity and mortality, and in resource-rich countries these children appear to have immunologic derangements (258-272). It should be noted that maternal infections with pathogens other than HIV have been associated with immune 
perturbations in the offspring, even in the absence of transmission (256). Compared to unexposed infants, HEU have lower $\mathrm{CD}^{+} \mathrm{T}$-cell counts with associated reduced thymic output, decreased efficiency of cloning progenitors, and increased serum IL-7 (266, 270, 273). In response to polyclonal stimulation in vitro, production of IL-10 is increased and IL-2 is decreased in HEU suggesting an alteration of T-cell activation $(268,274)$.

Furthermore, decreased production of IL-12 in cord blood cells suggest that the function of APC may also be altered (259). Finally, studies on responses to vaccination are inconsistent (275-279). These differences may in large part be due to differences in maternal health. Deficiencies among the HEU appear to be highly correlated with maternal CD4 $4^{+} \mathrm{T}$-cell count, so studies with healthier mothers would most likely report little or no effect while those with women with more advanced disease would find associations. In addition, maternal health appears to influence maternal antibody transfer, which may also influence infant response to vaccination $(275,280,281)$.

Although data on immune responses to vaccines are unclear, the clinical effects are not. HEU children born to women with advanced HIV disease are up to twice as likely to die in the first two years of life $(97,251)$, and this outcome is independent of both maternal morbidity and mortality and the separation of mother and infant due to maternal hospitalizations (282). Additionally, HEU children have more episodes of acute and persistent diarrhea, are 6 times more likely to fail antibiotic therapy when hospitalized with pneumonia than equally sick unexposed infants, have more infections with common neonatal pathogens (cytomegalovirus, group A streptococcus, and group B streptococcus), and have an unexpected number of severe infections caused by uncommon pathogens (Pneumocystis jirovecii) (252, 260, 263, 283-290).

A key question in the field is whether maternal ART will improve the health of HEU children. The only study that has made this claim failed to separate out the effects of reduced HIV transmission (291). Although HIV treatment obviously has substantial health benefits, ART does not reverse all the immunologic derangements associated with HIV infection particularly in persons with advanced disease. Non-mucosal T-cell levels and function are restored, but abnormalities in $\mathrm{B}$ cells and other innate pathways persist even when $\mathrm{CD} 4^{+} \mathrm{T}$ cell counts have returned to normal (292-295). Even in developed countries, HIV-infected adults with low $\mathrm{CD} 4^{+} \mathrm{T}$-cell nadirs are at increased risk for pneumococcal disease, despite $\mathrm{CD} 4^{+} \mathrm{T}$-cell recovery, and in the developing world, ART-treated adults remain at increased risk for TB $(296,297)$. Both pneumococcal disease and TB are significant causes of infant morbidity and mortality in areas of the world where HIV is endemic. Maternal immunity particularly through breastfeeding protects HIV-negative children from these diseases. (298300). Additionally, many markers of immune activation/inflammation do not return to normal levels even after years of viral suppression (301), and some appear to be unaffected by $\operatorname{ART}(225,301)$. Chronic maternal inflammation has been associated with untoward effects on the developing fetus and may also contribute to the abnormalites in HEU infants (256).

Questions about mechanisms underlying the vulnerabilities of HEU infants are not academic; these children experience unacceptable levels of morbidity and mortality and interventions to ensure their health are urgently needed. Given the fundamental link between maternal and infant health, it is likely that the immune dysregulation that persists on suppressive ART will profoundly influence this process. Thoughtful clinical studies should be done to establish whether these vulnerabilities persist despite maternal ART, and biologic specimens from these children should be used to probe pathogenic mechanisms. These studies have potential significance not only for public health interventions but may increase our understanding of child immune development and HIV derangements of mucosal immunity. 


\section{Lessons from pathogenic and non-pathogenic primate models of infection}

Studies of human infants, particular at mucosal sites, are inherently difficult to perform, and therefore much of our understanding of early pathogenesis comes from primate models of infection. Many important similarities between pathogenic models of SIV and HIV exist and strongly support the use of these models in MTCT: (i) pathogenic SIV and simian-human immunodeficiency virus (SHIV) can be transmitted to infant macaques at different stages of gestation including in utero and during breastfeeding (302-311), (ii) infant macaques progress more rapidly (usually within 6 months) to simian AIDS (SAIDS) than adult macaques, and (iii) in utero transmission is associated with more severe disease than breast milk transmission (312). Furthermore, like human fetuses, infant macaques have a higher prevalence of Tregs in the peripheral blood and lymphoid tissues, which might interfere with SIV-specific $\mathrm{CD}^{+}{ }^{+} \mathrm{T}$-cell responses, subsequently impairing $\mathrm{CD} 8^{+} \mathrm{T}$-cell and antibody responses, therefore contributing to the accelerated disease progression (313). Interestingly, $\mathrm{CD}^{+} \mathrm{T}$-cell-depleted adult rhesus macaques (RMs) challenged with SIV lack the typical post-peak decline in viremia despite $\mathrm{CD} 8^{+} \mathrm{T}$-cell and B-cell-mediated SIV-specific immune responses with a plasma viral load curve similar to HIV-infected infants (314). Therefore, the functional defect in HIV-infected infant $\mathrm{CD}^{+}{ }^{+} \mathrm{T}$ cells leads to a viremia similar to $\mathrm{CD} 4^{+}$ T-cell-depleted adult RMs. Following both intravenous and oral SIV transmission, infant macaques suffer rapid $\mathrm{CD}^{+}{ }^{+} \mathrm{T}$-cell loss in the intestinal mucosa (315), and the tonsil, esophageal, and intestinal mucosa have been identified as primary replication sites (303, $316,317)$. A difference in the localization of memory $\mathrm{CD} 4^{+} \mathrm{CCR} 5^{+} \mathrm{T}$ cells appears to exist between neonatal macaques and neonatal humans with subepithelial localization of $\mathrm{CD}^{+} \mathrm{CCR}^{+} \mathrm{T}$ cells in the lamina propria of neonatal macaques (220) versus epithelial localization of $\mathrm{CD}^{+} \mathrm{CCR}^{+} \mathrm{T}$ cells in human fetuses and neonates (15). How critical this difference will be in early HIV pathogenesis is unknown. Interestingly, transient infection or occult systemic low-level infection has been documented in both adult and infant macaque models of SIV and SHIV $(312,318-320)$. Notably, in a few cases of low-level infection, rebound viremia occurred following a year or more of aviremic survival (318-320). The implications of these findings in reference to the recent 'functional cure' of an infant (321) still need to be determined (see section on the possibility of cure below). Further study of pathogenic macaque models will increase our understanding of the initial stages of HIV infection in human infants and factors critical to viral control while study of nonpathogenic primate models may elucidate factors necessary to attenuate HIV infection.

Thousands of years of co-evolution with species-specific strains of SIV have led to mostly nonpathogenic infections associated with high levels of virus replication (322-326) in over 40 species of African nonhuman primates (327, 328). Interestingly, MTCT of SIV infection in these 'natural hosts' [sooty mangabeys (SMs), African green monkeys (AGMs), and mandrills] is rare, occurring at a rate of $<7 \%$ in SMs and even less in AGMs and mandrills (329-331). Preliminary evidence attributes the low rate of MTCT to low-levels of target cells in the infants, such as activated $\mathrm{CD} 4^{+} \mathrm{CCR} 5^{+} \mathrm{T}$ cells (329). When natural host infants do acquire SIV infection, levels of viral replication are significantly lower than their adult counterparts in direct opposition to human HIV infection. Whether the decreased viremia is due to decreased levels of immune activation and the tolerogenic fetal milieu or other mechanisms requires further study.

\section{Pediatric response to ART and the possibility of 'cure'}

Effective ART has transformed pediatric HIV into a chronic disease. Early virologic suppression is associated with normalization of B and T-cell numbers and function (204, 332-340). Increased thymic function in HIV-infected children and adolescents enhances their immunologic recovery $(341,342)$. 
Not unexpectedly, the benefits of early ART are most pronounced in younger children who are at greatest risk for death and disease progression (343-348). A randomized clinical trial of perinatally HIV-infected infants (median age 1.7 years), without evidence of immunosuppression (\% CD4 cells $>25 \%$, absolute CD4 >1,500 cells/ $\mu \mathrm{l}$ ), found that early ART reduced mortality and disease progression by approximately $75 \%$ (332). In contrast, a randomized clinical trial of early versus deferred therapy in older children (median age 6.4 years) did not detect differences in AIDS-free survival, morbidity, or neurodevelopmental outcome $(349,350)$. Unfortunately, the low event rate underpowered this study, precluding the detection of significant differences between groups. Moreover, there were too few children under 3 years of age for a subgroup analysis. Although this study is inconclusive, it emphasizes the marked age-related differences in survival and how survivor bias can impact pediatric studies (Figs 4 and 5).

Early infant treatment not only modifies clinical disease progression, it may also influence the size and half-life of latent-viral reservoirs established early in infection. These reservoirs represent a major barrier to eradication (351-357), and early studies measuring the recovery of replication-competent HIV from quiescent $\mathrm{CD}^{+} \mathrm{T}$ cells did not find significant differences between children and adults $(358,359)$. However, a recent study of early treated children suggests that that early therapy decreases the size and half-life of the resting CD4 ${ }^{+}$ T-cell latent reservoir (360). Perinatally infected adolescents who started ART in the first few months of life have been reported to have lower levels of proviral HIV DNA, replication-competent virus, and residual viremia compared to age-matched children treated later in life (361). Interestingly, in contrast to adults, early-treated children lack detectable HIV-specific antibodies and $\mathrm{CD}^{+} \mathrm{T}$-cell responses, suggesting a fundamental difference in HIV pathogenesis (361). Finally, a recent case report of a 26-month old infant who received ART from 30 hours of age to 18 months and now appears to be 'functionally' cured of HIV infection following ART discontinuation is tantalizing (321). Early treatment in macaques with drug resistant virus has been associated with a functional cure in SIV-infected animals after many years of viral suppression (362). Whether this human case will be confirmed and replicated is uncertain. Previous reports of 'transient' infant infection did not survive scrutiny (363).

Although speculative, we hypothesize that in infants, rapid, early inhibition of HIV replication turns the pathogenic paradigm on its head. Developmental changes that place an infant at great disadvantage (high levels of $\mathrm{CD}^{+} \mathrm{T}$ cells with rapid rates of cell turn-over, a predisposition to tolerogenic immune responses coupled with a Th17-cell bias after stimulation and a leaky gut) may be advantageous in the setting of effective antiretroviral suppression. The regenerative capacity and tolerogenic milieu that previously fueled viral replication may now accelerate immune restoration, inhibit subsequent rounds of viral replication, and control inflammatory responses during healing. The propensity of neonatal $\mathrm{CD}^{+} \mathrm{T}$ cells to develop into Th17 cells may help restore the intestinal epithelium and even exert antiviral responses (364). Poorly understood neonatal adaptations that impede immune activation in response to a 'leaky' gut may also play a role. The alternative hypothesis that antiretrovirals shield the vulnerable immune system allowing it to mature and control viral replication is inconsistent with the absence of detectable immune responses in early treated children.

It now appears that adults, like children, benefit from therapy early in the course of infection with greater recovery of $\mathrm{CD}^{+}{ }^{+} \mathrm{T}$-cell numbers (365), lower virologic set points, and a decreased size of the latent reservoir; however, the rate of decay of the latent reservoir appears to be unaffected (351). These benefits also appear to be independent of HIV-specific T-cell immunity (366). Whether adults with their age-related immune responses will be able to achieve a functional cure is a question of great interest. However, given the difficulty in 
identifying adults during acute infection, the full benefit of immediate therapy or potential cure strategies (367) may be better realized in infants where the timing of infection can be more readily established and immediate ART begun.

\section{Concluding remarks}

Pediatric HIV infection and the immune response (or lack of response) to HIV pose unique challenges and offer insight into immunologic factors unobtainable by the study of adult populations. The striking age-related changes in disease progression coupled with an increased understanding of normal immune development may shed new light on the immunopathology of HIV disease. Defining factors in breast milk that mitigate HIV transmission and slow disease progression may suggest new strategies for therapeutic and preventative efforts. Finally, the study of HEU children may provide a window into the limits of ART-induced immune reconstitution.

\section{Acknowledgments}

We thank Drs. John Sleasman, Steven Douglas, and Paul Krogstad for helpful discussions and critical review of the manuscript. This work was supported by grants from the National Institute of Health (R01 HD 39611, R01 HD 40777, R01 HD 57617, AI 100147) and the International Maternal Pediatric Adolescent AIDS Clinical Trials Group (IMPAACT). Overall support for IMPAACT was provided by the National Institute of Allergy and Infectious Diseases (NIAID) (U01 AI 68632), the Eunice Kennedy Shriver National Institute of Child Health and Human Development (NICHD), and the National Institute of Mental Health (NIMH) (AI 68632). G.M.A. is an Elizabeth Glaser Pediatric AIDS Foundation Scientist.

\section{References}

1. Rates of mother-to-child transmission of HIV-1 in Africa, America, and Europe: results from 13 perinatal studies. The Working Group on Mother-To-Child Transmission of HIV. J Acquir Immune Defic Syndr Hum Retrovirol. 1995; 8:506-510. [PubMed: 7697448]

2. Taha TE, et al. Association of recent HIV infection and in-utero HIV-1 transmission. AIDS. 2011; 25:1357-1364. [PubMed: 21572305]

3. Aldrovandi GM, Kuhn L. What infants and breasts can teach us about natural protection from HIV infection. J Infect Dis. 2010; 202(Suppl):S366-S370. [PubMed: 20887226]

4. Adams KM, Nelson JL. Microchimerism: an investigative frontier in autoimmunity and transplantation. JAMA. 2004; 291:1127-1131. [PubMed: 14996783]

5. Lee TH, Chafets DM, Biggar RJ, McCune JM, Busch MP. The role of transplacental microtransfusions of maternal lymphocytes in in utero HIV transmission. J Acquir Immune Defic Syndr. 2010; 55:143-147. [PubMed: 20683195]

6. Biggar RJ, et al. The role of transplacental microtransfusions of maternal lymphocytes in HIV transmission to newborns. AIDS. 2008; 22:2251-2256. [PubMed: 18981764]

7. Zack JA, Arrigo SJ, Weitsman SR, Go AS, Haislip A, Chen IS. HIV-1 entry into quiescent primary lymphocytes: molecular analysis reveals a labile, latent viral structure. Cell. 1990; 61:213-222. [PubMed: 2331748]

8. Mold JE, et al. Maternal alloantigens promote the development of tolerogenic fetal regulatory $\mathrm{T}$ cells in utero. Science. 2008; 322:1562-1565. [PubMed: 19056990]

9. Flanagan KL, et al. The effect of placental malaria infection on cord blood and maternal immunoregulatory responses at birth. Eur J Immunol. 2010; 40:1062-1072. [PubMed: 20039298]

10. Legrand FA, et al. Strong HIV-1-specific T cell responses in HIV-1-exposed uninfected infants and neonates revealed after regulatory T cell removal. PloS One. 2006; 1:e102. [PubMed: 17183635]

11. Kumar SB, et al. Elevated cytokine and chemokine levels in the placenta are associated with inutero HIV-1 mother-to-child transmission. AIDS. 2012; 26:685-694. [PubMed: 22301415]

12. Mwanyumba F, et al. Placental inflammation and perinatal transmission of HIV-1. Journal of acquired immune deficiency syndromes. 2002; 29:262-269. [PubMed: 11873075] 
13. St Louis ME, et al. Risk for perinatal HIV-1 transmission according to maternal immunologic, virologic, and placental factors. JAMA. 1993; 269:2853-2859. [PubMed: 8098783]

14. Wabwire-Mangen F, et al. Placental membrane inflammation and risks of maternal-to-child transmission of HIV-1 in Uganda. J Acquir Immune Defic Syndr. 1999; 22:379-385. [PubMed: 10634200]

15. Bunders MJ, et al. Memory CD4(+)CCR5(+) T cells are abundantly present in the gut of newborn infants to facilitate mother-to-child transmission of HIV-1. Blood. 2012; 120:4383-4390. [PubMed: 23033270]

16. Ho WZ, Lioy J, Song L, Cutilli JR, Polin RA, Douglas SD. Infection of cord blood monocytederived macrophages with human immunodeficiency virus type 1. Journal of virology. 1992; 66:573-579. [PubMed: 1727500]

17. Reinhardt PP, Reinhardt B, Lathey JL, Spector SA. Human cord blood mononuclear cells are preferentially infected by non-syncytium-inducing, macrophage-tropic human immunodeficiency virus type 1 isolates. J Clin Microbiol. 1995; 33:292-297. [PubMed: 7714181]

18. Sundaravaradan V, Saxena SK, Ramakrishnan R, Yedavalli VR, Harris DT, Ahmad N. Differential HIV-1 replication in neonatal and adult blood mononuclear cells is influenced at the level of HIV-1 gene expression. Proc Natl Acad Sci USA. 2006; 103:11701-11706. [PubMed: 16868088]

19. Tugizov SM, et al. Differential transmission of HIV traversing fetal oral/intestinal epithelia and adult oral epithelia. J Virol. 2012; 86:2556-2570. [PubMed: 22205732]

20. Joubert BR, Franceschini N, Mwapasa V, North KE, Meshnick SR. Regulation of CCR5 expression in human placenta: insights from a study of mother-to-child transmission of HIV in Malawi. PloS One. 2010; 5:e9212. [PubMed: 20169157]

21. Aguilar-Jimenez W, Zapata W, Rugeles MT. Differential expression of human beta defensins in placenta and detection of allelic variants in the DEFB1 gene from HIV-1 positive mothers. Biomedica. 2011; 31:44-54. [PubMed: 22159483]

22. Patterson BK, et al. Leukemia inhibitory factor inhibits HIV-1 replication and is upregulated in placentae from nontransmitting women. J Clin Invest. 2001; 107:287-294. [PubMed: 11160152]

23. Johnson EL, Chakraborty R. Placental Hofbauer cells limit HIV-1 replication and potentially offset mother to child transmission (MTCT) by induction of immunoregulatory cytokines. Retrovirology. 2012; 9:101. [PubMed: 23217137]

24. Marlin R, et al. Decidual soluble factors participate in the control of HIV-1 infection at the maternofetal interface. Retrovirology. 2011; 8:58. [PubMed: 21767373]

25. Elective caesarean-section versus vaginal delivery in prevention of vertical HIV-1 transmission: a randomised clinical trial. Lancet. 1999; 353:1035-1039. [PubMed: 10199349]

26. Mandelbrot L, et al. Frequent detection of HIV-1 in the gastric aspirates of neonates born to HIVinfected mothers. AIDS. 1999; 13:2143-2149. [PubMed: 10546868]

27. Stiehm ER, et al. Efficacy of zidovudine and human immunodeficiency virus (HIV) hyperimmune immunoglobulin for reducing perinatal HIV transmission from HIV-infected women with advanced disease: results of Pediatric AIDS Clinical Trials Group protocol 185. J Infect Dis. 1999; 179:567-575. [PubMed: 9952362]

28. Zinkernagel RM. Maternal antibodies, childhood infections, and autoimmune diseases. N Engl J Med. 2001; 345:1331-1335. [PubMed: 11794153]

29. Siegrist CA. Mechanisms by which maternal antibodies influence infant vaccine responses: review of hypotheses and definition of main determinants. Vaccine. 2003; 21:3406-3412. [PubMed: 12850349]

30. Hessell AJ, et al. Effective, low-titer antibody protection against low-dose repeated mucosal SHIV challenge in macaques. Nat Med. 2009; 15:951-954. [PubMed: 19525965]

31. Hessell AJ, et al. Broadly neutralizing human anti-HIV antibody $2 \mathrm{G} 12$ is effective in protection against mucosal SHIV challenge even at low serum neutralizing titers. PLoS Pathogens. 2009; 5:e1000433. [PubMed: 19436712]

32. Ng CT, et al. Passive neutralizing antibody controls SHIV viremia and enhances B cell responses in infant macaques. Nat Med. 2010; 16:1117-1119. [PubMed: 20890292] 
33. Nishimura Y, et al. Determination of a statistically valid neutralization titer in plasma that confers protection against simian-human immunodeficiency virus challenge following passive transfer of high-titered neutralizing antibodies. J Virol. 2002; 76:2123-2130. [PubMed: 11836389]

34. Parren PW, et al. Antibody protects macaques against vaginal challenge with a pathogenic R5 simian/human immunodeficiency virus at serum levels giving complete neutralization in vitro. $\mathrm{J}$ Virol. 2001; 75:8340-8347. [PubMed: 11483779]

35. Lewis P, et al. Cell-free human immunodeficiency virus type 1 in breast milk. J Infect Dis. 1998; 177:34-39. [PubMed: 9419167]

36. Heath L, et al. Restriction of HIV-1 genotypes in breast milk does not account for the population transmission genetic bottleneck that occurs following transmission. PloS One. 2010; 5:e10213. [PubMed: 20422033]

37. Semrau K, et al. Temporal and lateral dynamics of HIV shedding and elevated sodium in breast milk among HIV-positive mothers during the first 4 months of breast-feeding. J Acquir Immune Defic Syndr. 2008; 47:320-328. [PubMed: 18398972]

38. Thea DM, et al. Post-weaning breast milk HIV-1 viral load, blood prolactin levels and breast milk volume. AIDS. 2006; 20:1539-1547. [PubMed: 16847409]

39. Kantarci S, Koulinska IN, Aboud S, Fawzi WW, Villamor E. Subclinical mastitis, cell-associated HIV-1 shedding in breast milk, and breast-feeding transmission of HIV-1. J Acquir Immune Defic Syndr. 2007; 46:651-654. [PubMed: 18043320]

40. Kuhn L, et al. Effects of early, abrupt weaning on HIV-free survival of children in Zambia. N Engl J Med. 2008; 359:130-141. [PubMed: 18525036]

41. Semrau K, et al. Dynamics of breast milk HIV-1 RNA with unilateral mastitis or abscess. Journal of acquired immune deficiency syndromes. 2012

42. Gray RR, et al. Multiple independent lineages of HIV-1 persist in breast milk and plasma. AIDS. 2011; 25:143-152. [PubMed: 21173592]

43. Gantt S, et al. Genetic analyses of HIV-1 env sequences demonstrate limited compartmentalization in breast milk and suggest viral replication within the breast that increases with mastitis. J Virol. 2010; 84:10812-10819. [PubMed: 20660189]

44. Salazar-Gonzalez JF, et al. Origin and evolution of HIV-1 in breast milk determined by singlegenome amplification and sequencing. J Virol. 2011; 85:2751-2763. [PubMed: 21191008]

45. Gray L, Fiscus S, Shugars D. HIV-1 variants from a perinatal transmission pair demonstrate similar genetic and replicative properties in tonsillar tissues and peripheral blood mononuclear cells. AIDS Res Hum Retroviruses. 2007; 23:1095-1104. [PubMed: 17919104]

46. Becquart P, Hocini H, Garin B, Sepou A, Kazatchkine MD, Belec L. Compartmentalization of the IgG immune response to HIV-1 in breast milk. AIDS. 1999; 13:1323-1331. [PubMed: 10449284]

47. Bulek K, Swaidani S, Aronica M, Li X. Epithelium: the interplay between innate and Th2 immunity. Immunol Cell Biol. 2010; 88:257-268. [PubMed: 20065993]

48. Coutsoudis A, Pillay K, Spooner E, Kuhn L, Coovadia HM. Influence of infant-feeding patterns on early mother-to-child transmission of HIV-1 in Durban, South Africa: a prospective cohort study. South African Vitamin A Study Group. Lancet. 1999; 354:471-476. [PubMed: 10465172]

49. Kuhn L, et al. High uptake of exclusive breastfeeding and reduced early post-natal HIV transmission. PloS One. 2007; 2:e1363. [PubMed: 18159246]

50. Iliff PJ, et al. Early exclusive breastfeeding reduces the risk of postnatal HIV-1 transmission and increases HIV-free survival. AIDS. 2005; 19:699-708. [PubMed: 15821396]

51. Coovadia HM, et al. Mother-to-child transmission of HIV-1 infection during exclusive breastfeeding in the first 6 months of life: an intervention cohort study. Lancet. 2007; 369:11071116. [PubMed: 17398310]

52. Piwoz EG, et al. The impact of safer breastfeeding practices on postnatal HIV-1 transmission in Zimbabwe. Am J Pub Health. 2007; 97:1249-1254. [PubMed: 17538064]

53. Lunney KM, et al. Associations between breast milk viral load, mastitis, exclusive breast-feeding, and postnatal transmission of HIV. Clin Infect Dis. 2010; 50:762-769. [PubMed: 20121424]

54. Effect of breastfeeding on infant and child mortality due to infectious diseases in less developed countries: a pooled analysis. WHO Collaborative Study Team on the Role of Breastfeeding on the Prevention of Infant Mortality. Lancet. 2000; 355:451-455. [PubMed: 10841125] 
55. Victora CG, et al. Evidence for protection by breast-feeding against infant deaths from infectious diseases in Brazil. Lancet. 1987; 2:319-322. [PubMed: 2886775]

56. Brown KH, Black RE, Lopez de Romana G, Creed de Kanashiro H. Infant-feeding practices and their relationship with diarrheal and other diseases in Huascar (Lima), Peru. Pediatrics. 1989; 83:31-40. [PubMed: 2909974]

57. Semrau K, et al. Exclusive breastfeeding, maternal HIV disease, and the risk of clinical breast pathology in HIV-infected, breastfeeding women. Am J Obstet Gynecol. 2011; 205:344 e341-344 e348. [PubMed: 21784403]

58. Semba RD, et al. Human immunodeficiency virus load in breast milk, mastitis, and mother-to-child transmission of human immunodeficiency virus type 1. J Infect Dis. 1999; 180:93-98. [PubMed: 10353866]

59. Embree JE, et al. Risk factors for postnatal mother-child transmission of HIV-1. AIDS. 2000; 14:2535-2541. [PubMed: 11101065]

60. John GC, et al. Correlates of mother-to-child human immunodeficiency virus type 1 (HIV-1) transmission: association with maternal plasma HIV-1 RNA load, genital HIV-1 DNA shedding, and breast infections. J Infect Dis. 2001; 183:206-212. [PubMed: 11120927]

61. Fawzi W, et al. Transmission of HIV-1 through breastfeeding among women in Dar es Salaam, Tanzania. J Acquir Immune Defic Syndr. 2002; 31:331-338. [PubMed: 12439210]

62. Lyimo MA, et al. Breast milk from Tanzanian women has divergent effects on cell-free and cellassociated HIV-1 infection in vitro. PloS One. 2012; 7:e43815. [PubMed: 22952771]

63. Farquhar C, et al. CC and CXC chemokines in breastmilk are associated with mother-to-child HIV-1 transmission. Curr HIV Res. 2005; 3:361-369. [PubMed: 16250882]

64. Bosire R, et al. Longitudinal comparison of chemokines in breastmilk early postpartum among HIV-1-infected and uninfected Kenyan women. Breastfeeding Med. 2007; 2:129-138.

65. Lohman-Payne B, et al. Breast milk cellular HIV-specific interferon gamma responses are associated with protection from peripartum HIV transmission. AIDS. 2012; 26:2007-2016. [PubMed: 22948269]

66. Martin V, Maldonado A, Fernandez L, Rodriguez JM, Connor RI. Inhibition of human immunodeficiency virus type 1 by lactic acid bacteria from human breastmilk. Breastfeeding Med. 2010; 5:153-158.

67. Naarding MA, et al. Bile salt-stimulated lipase from human milk binds DC-SIGN and inhibits human immunodeficiency virus type 1 transfer to CD4+ T cells. Antimicrob Agents Chemother. 2006; 50:3367-3374. [PubMed: 17005819]

68. Walter J, et al. High concentrations of interleukin 15 in breast milk are associated with protection against postnatal HIV transmission. J Infect Dis. 2009; 200:1498-1502. [PubMed: 19835475]

69. Walter J, et al. Low and undetectable breast milk interleukin-7 concentrations are associated with reduced risk of postnatal HIV transmission. J Acquir Immune Defic Syndr. 2007; 46:200-207. [PubMed: 17667336]

70. Kuhn L, et al. Alpha-defensins in the prevention of HIV transmission among breastfed infants. J Acquir Immune Defic Syndr. 2005; 39:138-142. [PubMed: 15905728]

71. Bosire R, et al. Breast milk alpha-defensins are associated with HIV type 1 RNA and CC chemokines in breast milk but not vertical HIV type 1 transmission. AIDS Res Hum Retroviruses. 2007; 23:198-203. [PubMed: 17331027]

72. Villamor E, et al. Long-chain n-6 polyunsaturated fatty acids in breast milk decrease the risk of HIV transmission through breastfeeding. Am J Clin Nutr. 2007; 86:682-689. [PubMed: 17823433]

73. Bode L, et al. Human milk oligosaccharide concentration and risk of postnatal transmission of HIV through breastfeeding. Am J Clin Nutr. 2012; 96:831-839. [PubMed: 22894939]

74. Arsenault JE, Webb AL, Koulinska IN, Aboud S, Fawzi WW, Villamor E. Association between breast milk erythropoietin and reduced risk of mother-to-child transmission of HIV. J Infect Dis. 2010; 202:370-373. [PubMed: 20557236]

75. Kuhn L, et al. Hiv-specific secretory IgA in breast milk of HIV-positive mothers is not associated with protection against HIV transmission among breast-fed infants. J Ped. 2006; 149:611-616. 
76. Mabuka J, Nduati R, Odem-Davis K, Peterson D, Overbaugh J. HIV-specific antibodies capable of ADCC are common in breastmilk and are associated with reduced risk of transmission in women with high viral loads. PLoS Pathog. 2012; 8:e1002739. [PubMed: 22719248]

77. Walter J, Kuhn L, Aldrovandi GM. Advances in basic science understanding of mother-to-child HIV-1 transmission. Curr Opin HIV AIDS. 2008; 3:146-150. [PubMed: 19372957]

78. Lehman DA, Farquhar C. Biological mechanisms of vertical human immunodeficiency virus (HIV-1) transmission. Rev Med Virol. 2007; 17:381-403. [PubMed: 17542053]

79. Naarding MA, et al. Lewis X component in human milk binds DC-SIGN and inhibits HIV-1 transfer to CD4+ T lymphocytes. J Clin Invest. 2005; 115:3256-3264. [PubMed: 16239964]

80. Saeland E, de Jong MA, Nabatov AA, Kalay H, Geijtenbeek TB, van Kooyk Y. MUC1 in human milk blocks transmission of human immunodeficiency virus from dendritic cells to T cells. Mol Immunol. 2009; 46:2309-2316. [PubMed: 19406479]

81. Hong P, Ninonuevo MR, Lee B, Lebrilla C, Bode L. Human milk oligosaccharides reduce HIV-1gp120 binding to dendritic cell-specific ICAM3-grabbing non-integrin (DC-SIGN). Br J Nutr. 2009; 101:482-486. [PubMed: 19230080]

82. Ruben FL, Holzman IR, Fireman P. Responses of lymphocytes from human colostrum or milk to influenza antigens. Am J Obstet Gynecol. 1982; 143:518-522. [PubMed: 7091222]

83. Scott R, Scott M, Toms GL. Cellular reactivity to respiratory syncytial virus in human colostrum and breast milk. J Med Virol. 1985; 17:83-93. [PubMed: 4045438]

84. Sabbaj S, et al. Human immunodeficiency virus-specific CD8(+) T cells in human breast milk. J Virol. 2002; 76:7365-7373. [PubMed: 12097549]

85. Bertotto A, et al. Human breast milk T lymphocytes display the phenotype and functional characteristics of memory T cells. Eur J Immunol. 1990; 20:1877-1880. [PubMed: 2120066]

86. Sabbaj S, Ibegbu CC, Kourtis AP. Cellular immunity in breast milk: implications for postnatal transmission of HIV-1 to the infant. Adv Exp Med Biol. 2012; 743:161-169. [PubMed: 22454348]

87. Sabbaj S, et al. Breast milk-derived antigen-specific CD8+ T cells: an extralymphoid effector memory cell population in humans. J Immunol. 2005; 174:2951-2956. [PubMed: 15728507]

88. Jain L, Vidyasagar D, Xanthou M, Ghai V, Shimada S, Blend M. In vivo distribution of human milk leucocytes after ingestion by newborn baboons. Arch Dis Childhood. 1989; 64:930-933. [PubMed: 2774634]

89. Schnorr KL, Pearson LD. Intestinal absorption of maternal leucocytes by newborn lambs. J Repro Immunol. 1984; 6:329-337.

90. Head JR, Beer AE, Billingham RE. Significance of the cellular component of the maternal immunologic endowment in milk. Transplant Proc. 1977; 9:1465-1471. [PubMed: 327642]

91. Weiler IJ, Hickler W, Sprenger R. Demonstration that milk cells invade the suckling neonatal mouse. Am J Repro Immunol. 1983; 4:95-98.

92. Zhou L, et al. Two independent pathways of maternal cell transmission to offspring: through placenta during pregnancy and by breast-feeding after birth. Immunology. 2000; 101:570-580. [PubMed: 11122462]

93. Ranganathan UD, Larsen MH, Kim J, Porcelli SA, Jacobs WR Jr, Fennelly GJ. Recombinant proapoptotic Mycobacterium tuberculosis generates CD8+ T cell responses against human immunodeficiency virus type 1 Env and M. tuberculosis in neonatal mice. Vaccine. 2009; 28:152161. [PubMed: 19808028]

94. Mahlokozera T, et al. The magnitude and kinetics of the mucosal HIV-specific CD8+ T lymphocyte response and virus RNA load in breast milk. PloS One. 2011; 6:e23735. [PubMed: 21886819]

95. Belec L, Kourtis AP. B lymphocyte-derived humoral immune defenses in breast milk transmission of the HIV-1. Adv Exp Med Biol. 2012; 743:139-160. [PubMed: 22454347]

96. Lallemant M, et al. A trial of shortened zidovudine regimens to prevent mother-to-child transmission of human immunodeficiency virus type 1. Perinatal HIV Prevention Trial (Thailand) Investigators. N Engl J Med. 2000; 343:982-991. [PubMed: 11018164]

97. Marinda E, et al. Child mortality according to maternal and infant HIV status in Zimbabwe. Ped Infec Dis J. 2007; 26:519-526. 
98. Fawzi W, et al. Predictors of intrauterine and intrapartum transmission of HIV-1 among Tanzanian women. AIDS. 2001; 15:1157-1165. [PubMed: 11416718]

99. Becquet R, et al. Children who acquire HIV infection perinatally are at higher risk of early death than those acquiring infection through breastmilk: a meta-analysis. PloS One. 2012; 7:e28510. [PubMed: 22383946]

100. Level and pattern of HIV-1-RNA viral load over age: differences between girls and boys? AIDS. 2002; 16:97-104. [PubMed: 11741167]

101. Dunn D. Short-term risk of disease progression in HIV-1-infected children receiving no antiretroviral therapy or zidovudine monotherapy: a meta-analysis. Lancet. 2003; 362:16051611. [PubMed: 14630440]

102. McIntosh K, et al. Age- and time-related changes in extracellular viral load in children vertically infected by human immunodeficiency virus. Ped Infect Dis J. 1996; 15:1087-1091.

104. Sperduto AR, Bryson YJ, Chen IS. Increased susceptibility of neonatal monocyte/macrophages to HIV-1 infection. AIDS Res Hum Retroviruses. 1993; 9:1277-1285. [PubMed: 8142145]

105. Pillay T, et al. Unique acquisition of cytotoxic T-lymphocyte escape mutants in infant human immunodeficiency virus type 1 infection. J Virol. 2005; 79:12100-12105. [PubMed: 16140787]

106. Thobakgale CF, et al. Impact of HLA in mother and child on disease progression of pediatric human immunodeficiency virus type 1 infection. J Virol. 2009; 83:10234-10244. [PubMed: 19605475]

107. Dunn D, et al. Current CD4 cell count and the short-term risk of AIDS and death before the availability of effective antiretroviral therapy in HIV-infected children and adults. J Infect Dis. 2008; 197:398-404. [PubMed: 18248303]

108. Sanchez-Schmitz G, Levy O. Development of newborn and infant vaccines. Sci Trans Med. 2011; 3:90ps27.

109. Haynes BF, Heinly CS. Early human T cell development: analysis of the human thymus at the time of initial entry of hematopoietic stem cells into the fetal thymic microenvironment. J Exp Med. 1995; 181:1445-1458. [PubMed: 7699329]

110. Lewis, DB.; Wilson, CB. Developmental immunology and role of host defenses in fetal and neonatal susceptibility to infection. 7th ed.. Philadelphia: WB Saunders; 2011.

111. Corbett NP, et al. Ontogeny of Toll-like receptor mediated cytokine responses of human blood mononuclear cells. PloS One. 2010; 5:e15041. [PubMed: 21152080]

112. Nguyen M, et al. Acquisition of adult-like TLR4 and TLR9 responses during the first year of life. PloS One. 2010; 5:e10407. [PubMed: 20442853]

113. Burl S, et al. Age-dependent maturation of Toll-like receptor-mediated cytokine responses in Gambian infants. PloS One. 2011; 6:e18185. [PubMed: 21533209]

114. Belderbos ME, Levy O, Stalpers F, Kimpen JL, Meyaard L, Bont L. Neonatal plasma polarizes TLR4-mediated cytokine responses towards low IL-12p70 and high IL-10 production via distinct factors. PloS One. 2012; 7:e33419. [PubMed: 22442690]

115. Levy O, Coughlin M, Cronstein BN, Roy RM, Desai A, Wessels MR. The adenosine system selectively inhibits TLR-mediated TNF-alpha production in the human newborn. J Immunol. 2006; 177:1956-1966. [PubMed: 16849509]

116. Levy O. Innate immunity of the newborn: basic mechanisms and clinical correlates. Nat Rev Immunol. 2007; 7:379-390. [PubMed: 17457344]

117. Levy O. Innate immunity of the human newborn: distinct cytokine responses to LPS and other Toll-like receptor agonists. J Endotoxin Res. 2005; 11:113-116. [PubMed: 15949138]

118. Belderbos ME, et al. Skewed pattern of Toll-like receptor 4-mediated cytokine production in human neonatal blood: low LPS-induced IL-12p70 and high IL-10 persist throughout the first month of life. Clin Immunol. 2009; 133:228-237. [PubMed: 19648060]

119. Rose S, Lichtenheld M, Foote MR, Adkins B. Murine neonatal CD4+ cells are poised for rapid Th2 effector-like function. J Immunol. 2007; 178:2667-2678. [PubMed: 17312108]

120. Webster RB, Rodriguez Y, Klimecki WT, Vercelli D. The human IL-13 locus in neonatal CD4+ $\mathrm{T}$ cells is refractory to the acquisition of a repressive chromatin architecture. J Biol Chem. 2007; 282:700-709. [PubMed: 17090525] 
121. Weitzel RP, et al. microRNA 184 regulates expression of NFAT1 in umbilical cord blood CD4+ T cells. Blood. 2009; 113:6648-6657. [PubMed: 19286996]

122. Adkins B, Leclerc C, Marshall-Clarke S. Neonatal adaptive immunity comes of age. Nat Rev Immunol. 2004; 4:553-564. [PubMed: 15229474]

123. Haines CJ, et al. Human CD4+ T cell recent thymic emigrants are identified by protein tyrosine kinase 7 and have reduced immune function. J Exp Med. 2009; 206:275-285. [PubMed: 19171767]

124. Grindebacke H, et al. Dynamic development of homing receptor expression and memory cell differentiation of infant CD4+CD25high regulatory T cells. J Immunol. 2009; 183:4360-4370. [PubMed: 19734224]

125. Mold JE, et al. Fetal and adult hematopoietic stem cells give rise to distinct $\mathrm{T}$ cell lineages in humans. Science. 2010; 330:1695-1699. [PubMed: 21164017]

126. Ivanov II, et al. Induction of intestinal Th17 cells by segmented filamentous bacteria. Cell. 2009; 139:485-498. [PubMed: 19836068]

127. Ivanov II, Littman DR. Segmented filamentous bacteria take the stage. Mucosal Immunol. 2010; 3:209-212. [PubMed: 20147894]

128. Ivanov II, et al. Specific microbiota direct the differentiation of IL-17-producing T-helper cells in the mucosa of the small intestine. Cell Host Microbe. 2008; 4:337-349. [PubMed: 18854238]

129. Gaboriau-Routhiau V, et al. The key role of segmented filamentous bacteria in the coordinated maturation of gut helper T cell responses. Immunity. 2009; 31:677-689. [PubMed: 19833089]

130. Brenchley JM, et al. Differential Th17 CD4 T-cell depletion in pathogenic and nonpathogenic lentiviral infections. Blood. 2008; 112:2826-2835. [PubMed: 18664624]

131. Josefowicz SZ, Lu LF, Rudensky AY. Regulatory T cells: mechanisms of differentiation and function. Annu Rev Immunol. 2012; 30:531-564. [PubMed: 22224781]

132. Murai M, Krause P, Cheroutre H, Kronenberg M. Regulatory T-cell stability and plasticity in mucosal and systemic immune systems. Mucosal immunol. 2010; 3:443-449. [PubMed: 20505662]

133. Black A, Bhaumik S, Kirkman RL, Weaver CT, Randolph DA. Developmental regulation of Th17-cell capacity in human neonates. Eur J Immunol. 2012; 42:311-319. [PubMed: 22101893]

134. Siegrist CA, Aspinall R. B-cell responses to vaccination at the extremes of age. Nat Rev Immunol. 2009; 9:185-194. [PubMed: 19240757]

135. Shearer WT, et al. Lymphocyte subsets in healthy children from birth through 18 years of age: the Pediatric AIDS Clinical Trials Group P1009 study. J Allergy Clin Immunol. 2003; 112:973-980. [PubMed: 14610491]

136. Schatorje EJ, Gemen EF, Driessen GJ, Leuvenink J, van Hout RW, de Vries E. Paediatric reference values for the peripheral T cell compartment. Scan J Immunol. 2012; 75:436-444.

137. Krogstad P, Uittenbogaart CH, Dickover R, Bryson YJ, Plaeger S, Garfinkel A. Primary HIV infection of infants: the effects of somatic growth on lymphocyte and virus dynamics. Clin Immunol. 1999; 92:25-33. [PubMed: 10413650]

138. Stiehm ER, Fudenberg HH. Serum levels of immune globulins in health and disease: a survey. Pediatrics. 1966; 37:715-727. [PubMed: 4956666]

139. Mastelic B, et al. Environmental and T cell-intrinsic factors limit the expansion of neonatal follicular T helper cells but may be circumvented by specific adjuvants. J Immunol. 2012; 189:5764-5772. [PubMed: 23162125]

140. Lundell AC, et al. Infant B cell memory differentiation and early gut bacterial colonization. J Immunol. 2012; 188:4315-4322. [PubMed: 22490441]

141. MA Saxonhouse, JS. Immunodeficiency diseases of the neonate. In: Alarcon, d, editor. Neonatal Hemotolgy. Cambridge University Press; 2009. p. 280-309.

142. Marchant A, et al. Newborns develop a Th1-type immune response to Mycobacterium bovis bacillus Calmette-Guerin vaccination. J Immunol. 1999; 163:2249-2255. [PubMed: 10438968]

143. Marchant A, et al. Mature CD8(+) T lymphocyte response to viral infection during fetal life. J Clin Invest. 2003; 111:1747-1755. [PubMed: 12782677] 
144. Marchant A, Goldman M. T cell-mediated immune responses in human newborns: ready to learn? Clin Exp Immunol. 2005; 141:10-18. [PubMed: 15958064]

145. Kollmann TR, et al. Neonatal innate TLR-mediated responses are distinct from those of adults. J Immunol. 2009; 183:7150-7160. [PubMed: 19917677]

146. Prendergast AJ, Klenerman P, Goulder PJ. The impact of differential antiviral immunity in children and adults. Nat Rev Immunol. 2012; 12:636-648. [PubMed: 22918466]

147. Insoft RM, Sanderson IR, Walker WA. Development of immune function in the intestine and its role in neonatal diseases. Ped Clin N Am. 1996; 43:551-571.

148. Grdic D, Hornquist E, Kjerrulf M, Lycke NY. Lack of local suppression in orally tolerant CD8deficient mice reveals a critical regulatory role of CD8+ T cells in the normal gut mucosa. $\mathrm{J}$ Immunol. 1998; 160:754-762. [PubMed: 9551910]

149. Nanthakumar $\mathrm{N}$, et al. The mechanism of excessive intestinal inflammation in necrotizing enterocolitis: an immature innate immune response. PloS One. 2011; 6:e17776. [PubMed: 21445298]

150. Claud EC, Lu L, Anton PM, Savidge T, Walker WA, Cherayil BJ. Developmentally regulated IkappaB expression in intestinal epithelium and susceptibility to flagellin-induced inflammation. Proc Natl Acad Sci USA. 2004; 101:7404-7408. [PubMed: 15123821]

151. Neu J, Walker WA. Necrotizing enterocolitis. N Engl J Med. 2011; 364:255-264. [PubMed: 21247316]

152. Brandtzaeg PE. Current understanding of gastrointestinal immunoregulation and its relation to food allergy. Ann NY Acad Sci. 2002; 964:13-45. [PubMed: 12023193]

153. Paiardini M, Frank I, Pandrea I, Apetrei C, Silvestri G. Mucosal immune dysfunction in AIDS pathogenesis. AIDS Rev. 2008; 10:36-46. [PubMed: 18385779]

154. Brenchley JM, Douek DC. Microbial translocation across the GI tract. Annu Rev Immunol. 2012; 30:149-173. [PubMed: 22224779]

155. Marchetti G, Tincati C, Silvestri G. Microbial Translocation in the Pathogenesis of HIV Infection and AIDS. Clin Microbiol Rev. 2013; 26:2-18. [PubMed: 23297256]

156. Dominguez-Bello MG, et al. Delivery mode shapes the acquisition and structure of the initial microbiota across multiple body habitats in newborns. Proc Natl Acad Sci USA. 2010; 107:11971-11975. [PubMed: 20566857]

157. Gronlund MM, Lehtonen OP, Eerola E, Kero P. Fecal microflora in healthy infants born by different methods of delivery: permanent changes in intestinal flora after cesarean delivery. J Ped Gastroenterol Nutr. 1999; 28:19-25.

158. Adlerberth I, et al. Reduced enterobacterial and increased staphylococcal colonization of the infantile bowel: an effect of hygienic lifestyle? Ped Res. 2006; 59:96-101.

159. Neu J, Rushing J. Cesarean versus vaginal delivery: long-term infant outcomes and the hygiene hypothesis. Clin Perinatol. 2011; 38:321-331. [PubMed: 21645799]

160. Koenig JE, et al. Succession of microbial consortia in the developing infant gut microbiome. Proc Natl Acad Sci USA. 2011; 108(Suppl):4578-4585. [PubMed: 20668239]

161. Yatsunenko T, et al. Human gut microbiome viewed across age and geography. Nature. 2012; 486:222-227. [PubMed: 22699611]

162. Renz H, Brandtzaeg P, Hornef M. The impact of perinatal immune development on mucosal homeostasis and chronic inflammation. Nat Rev Immunol. 2012; 12:9-23. [PubMed: 22158411]

163. Cornes JS. Number, size, and distribution of Peyer's patches in the human small intestine: Part I The development of Peyer's patches. Gut. 1965; 6:225-229. [PubMed: 18668776]

164. Gronlund MM, Arvilommi H, Kero P, Lehtonen OP, Isolauri E. Importance of intestinal colonisation in the maturation of humoral immunity in early infancy: a prospective follow up study of healthy infants aged 0-6 months. Arch Dis Childhood Fetal Neonatal Ed. 2000; 83:F186-F192. [PubMed: 11040166]

165. Sjogren YM, et al. Influence of early gut microbiota on the maturation of childhood mucosal and systemic immune responses. Clin Exp Allergy. 2009; 39:1842-1851. [PubMed: 19735274] 
166. Round JL, Mazmanian SK. Inducible Foxp3+ regulatory T-cell development by a commensal bacterium of the intestinal microbiota. Proc Natl Acad Sci USA. 2010; 107:12204-12209. [PubMed: 20566854]

167. Schwartz S, et al. A metagenomic study of diet-dependent interaction between gut microbiota and host in infants reveals differences in immune response. Genome Biol. 2012; 13:r32. [PubMed: 22546241]

168. Perez PF, et al. Bacterial imprinting of the neonatal immune system: lessons from maternal cells? Pediatrics. 2007; 119:e724-e732. [PubMed: 17332189]

169. Hunt KM, et al. Characterization of the diversity and temporal stability of bacterial communities in human milk. PloS One. 2011; 6:e21313. [PubMed: 21695057]

170. Isaacs CE. Human milk inactivates pathogens individually, additively, and synergistically. J Nutr. 2005; 135:1286-1288. [PubMed: 15867325]

171. Marcobal A, Sonnenburg JL. Human milk oligosaccharide consumption by intestinal microbiota. Clin Microbiol Infect. 2012; 18(Suppl):12-15. [PubMed: 22647041]

172. Bode L. Human milk oligosaccharides: every baby needs a sugar mama. Glycobiology. 2012; 22:1147-1162. [PubMed: 22513036]

173. Ganguli K, Meng D, Rautava S, Lu L, Walker WA, Nanthakumar N. Probiotics prevent necrotizing enterocolitis by modulating enterocyte genes that regulate innate immune-mediated inflammation. Am J Physiol Gastrointestinal Liver Physiol. 2013; 304:G132-G141.

174. Ganguli K, Walker WA. Treatment of necrotizing enterocolitis with probiotics. Gastroenterol Clin N Am. 2012; 41:733-746.

175. Breastfeeding and the use of human milk. Pediatrics. 2012; 129:e827-e841. [PubMed: 22371471]

176. Mata LJ, Urrutia JJ, Garcia B, Fernandez R, Behar M. Shigella infection in breast-fed Guatemalan indian neonates. Am J Dis Child. 1969; 117:142-146. [PubMed: 5763825]

177. Newburg DS, Ashkenazi S, Cleary TG. Human milk contains the Shiga toxin and Shiga-like toxin receptor glycolipid Gb3. J Infect Dis. 1992; 166:832-836. [PubMed: 1527419]

178. Jantscher-Krenn E, et al. The human milk oligosaccharide disialyllacto-N-tetraose prevents necrotising enterocolitis in neonatal rats. Gut. 2012; 61:1417-1425. [PubMed: 22138535]

179. Brandtzaeg P. The gut as communicator between environment and host: immunological consequences. Eur J Pharmacol. 2011; 668(Suppl):S16-S32. [PubMed: 21816150]

180. Catassi C, Bonucci A, Coppa GV, Carlucci A, Giorgi PL. Intestinal permeability changes during the first month: effect of natural versus artificial feeding. J Ped Gastroenterol Nutr. 1995; 21:383-386.

181. Boirivant M, et al. A transient breach in the epithelial barrier leads to regulatory T-cell generation and resistance to experimental colitis. Gastroenterology. 2008; 135:1612-1623. e1615. [PubMed: 18765239]

182. Lefevre CM, Sharp JA, Nicholas KR. Evolution of lactation: ancient origin and extreme adaptations of the lactation system. Annu Rev Genomics Hum Genet. 2010; 11:219-238. [PubMed: 20565255]

183. Vorbach C, Capecchi MR, Penninger JM. Evolution of the mammary gland from the innate immune system? BioEssays. 2006; 28:606-616. [PubMed: 16700061]

184. McClellan HL, Miller SJ, Hartmann PE. Evolution of lactation: nutrition v. protection with special reference to five mammalian species. Nutr Res Rev. 2008; 21:97-116. [PubMed: 19087365]

185. Brandtzaeg P. Mucosal immunity: integration between mother and the breast-fed infant. Vaccine. 2003; 21:3382-3388. [PubMed: 12850345]

186. Quigley MA, Kelly YJ, Sacker A. Breastfeeding and hospitalization for diarrheal and respiratory infection in the United Kingdom Millennium Cohort Study. Pediatrics. 2007; 119:e837-e842. [PubMed: 17403827]

187. Lawrence RM, Pane CA. Human breast milk: current concepts of immunology and infectious diseases. Curr Prob Ped Adolesc Health Care. 2007; 37:7-36.

188. Labbok MH, Clark D, Goldman AS. Breastfeeding: maintaining an irreplaceable immunological resource. Nat Rev Immunol. 2004; 4:565-572. [PubMed: 15229475] 
189. Iyengar SR, Walker WA. Immune factors in breast milk and the development of atopic disease. J Ped Gastro Nutr. 2012; 55:641-647.

190. Shulzhenko N, et al. Crosstalk between B lymphocytes, microbiota and the intestinal epithelium governs immunity versus metabolism in the gut. Nat Med. 2011; 17:1585-1593. [PubMed: 22101768]

191. Hamosh M, et al. Protective function of human milk: the milk fat globule. Semin Perinatol. 1999; 23:242-249. [PubMed: 10405194]

192. Silfverdal SA, Ekholm L, Bodin L. Breastfeeding enhances the antibody response to Hib and Pneumococcal serotype 6B and 14 after vaccination with conjugate vaccines. Vaccine. 2007; 25:1497-1502. [PubMed: 17097198]

193. Ngom PT, Collinson AC, Pido-Lopez J, Henson SM, Prentice AM, Aspinall R. Improved thymic function in exclusively breastfed infants is associated with higher interleukin 7 concentrations in their mothers' breast milk. Am J Clin Nutr. 2004; 80:722-728. [PubMed: 15321814]

194. Aspinall R, Prentice AM, Ngom PT. Interleukin 7 from maternal milk crosses the intestinal barrier and modulates T-cell development in offspring. PloS One. 2011; 6:e20812. [PubMed: 21738587]

195. Lack G. The concept of oral tolerance induction to foods. Nestle Nutrition workshop series Paediatric programme. 2007; 59:63-68. discussion 68-72. [PubMed: 17245091]

196. Garofalo RP, Goldman AS. Expression of functional immunomodulatory and anti-inflammatory factors in human milk. Clin Perinatol. 1999; 26:361-377. [PubMed: 10394492]

197. Gottrand F. Long-chain polyunsaturated fatty acids influence the immune system of infants. J Nutr. 2008; 138:1807S-1812S. [PubMed: 18716191]

198. Gdalevich M, Mimouni D, David M, Mimouni M. Breast-feeding and the onset of atopic dermatitis in childhood: a systematic review and meta-analysis of prospective studies. J Am Acad Dermatol. 2001; 45:520-527. [PubMed: 11568741]

199. Kull I, Wickman M, Lilja G, Nordvall SL, Pershagen G. Breast feeding and allergic diseases in infants-a prospective birth cohort study. Arch Dis Childhood. 2002; 87:478-481. [PubMed: 12456543]

200. Mimouni Bloch A, Mimouni D, Mimouni M, Gdalevich M. Does breastfeeding protect against allergic rhinitis during childhood? A meta-analysis of prospective studies. Acta Paediatr. 2002; 91:275-279. [PubMed: 12022298]

201. Bjorksten B, Sepp E, Julge K, Voor T, Mikelsaar M. Allergy development and the intestinal microflora during the first year of life. J Allergy Clin Immunol. 2001; 108:516-520. [PubMed: 11590374]

202. Penders J, et al. Gut microbiota composition and development of atopic manifestations in infancy: the KOALA Birth Cohort Study. Gut. 2007; 56:661-667. [PubMed: 17047098]

203. Ramduth D, et al. Detection of HIV type 1 gag-specific CD4(+) T cell responses in acutely infected infants. AIDS Res Hum Retroviruses. 2008; 24:265-270. [PubMed: 18284325]

204. Luzuriaga K, et al. Early therapy of vertical human immunodeficiency virus type 1 (HIV-1) infection: control of viral replication and absence of persistent HIV-1-specific immune responses. J Virol. 2000; 74:6984-6991. [PubMed: 10888637]

205. Thobakgale CF, et al. Human immunodeficiency virus-specific CD8+ T-cell activity is detectable from birth in the majority of in utero-infected infants. J Virol. 2007; 81:12775-12784. [PubMed: 17881456]

206. Lohman BL, et al. Longitudinal assessment of human immunodeficiency virus type 1 (HIV-1)specific gamma interferon responses during the first year of life in HIV-1-infected infants. J Virol. 2005; 79:8121-8130. [PubMed: 15956557]

207. Sandberg JK, et al. HIV-specific CD8+ T cell function in children with vertically acquired HIV-1 infection is critically influenced by age and the state of the CD4+ T cell compartment. J Immunol. 2003; 170:4403-4410. [PubMed: 12682278]

208. Pugatch D, Sullivan JL, Pikora CA, Luzuriaga K. Delayed generation of antibodies mediating human immunodeficiency virus type 1 -specific antibody-dependent cellular cytotoxicity in vertically infected infants. WITS Study Group. Women and Infants Transmission Study. J Infect Dis. 1997; 176:643-648. [PubMed: 9291310] 
209. Ziegner U, Campbell D, Weinhold K, Frank I, Rutstein R, Starr SE. Deficient antibody-dependent cellular cytotoxicity against human immunodeficiency virus (HIV)-expressing target cells in perinatal HIV infection. Clin Diagnost Lab Immunol. 1999; 6:718-724.

210. Farquhar C, John-Stewart G. The role of infant immune responses and genetic factors in preventing HIV-1 acquisition and disease progression. Clin Exp Immunol. 2003; 134:367-377. [PubMed: 14632739]

211. Shalekoff S, Gray GE, Tiemessen CT. Age-related changes in expression of CXCR4 and CCR5 on peripheral blood leukocytes from uninfected infants born to human immunodeficiency virus type 1-infected mothers. Clin Diagnost Lab Immunol. 2004; 11:229-234.

212. Tuttle DL, Coberley CR, Xie X, Kou ZC, Sleasman JW, Goodenow MM. Effects of human immunodeficiency virus type 1 infection on CCR5 and CXCR4 coreceptor expression on CD4 T lymphocyte subsets in infants and adolescents. AIDS Res Hum Retroviruses. 2004; 20:305-313. [PubMed: 15117454]

213. Veazey RS, Lackner AA. HIV swiftly guts the immune system. Nat Med. 2005; 11:469-470. [PubMed: 15875046]

214. Brenchley JM, et al. CD4+ T cell depletion during all stages of HIV disease occurs predominantly in the gastrointestinal tract. J Exp Med. 2004; 200:749-759. [PubMed: 15365096]

215. Mehandru S, Dandekar S. Role of the gastrointestinal tract in establishing infection in primates and humans. Curr Opin HIV AIDS. 2008; 3:22-27. [PubMed: 19372940]

216. Mehandru S, et al. Primary HIV-1 infection is associated with preferential depletion of CD4+ T lymphocytes from effector sites in the gastrointestinal tract. J Exp Med. 2004; 200:761-770. [PubMed: 15365095]

217. Favre D, et al. Critical loss of the balance between Th17 and T regulatory cell populations in pathogenic SIV infection. PLoS Pathogens. 2009; 5:e1000295. [PubMed: 19214220]

218. Raffatellu M, et al. Simian immunodeficiency virus-induced mucosal interleukin-17 deficiency promotes Salmonella dissemination from the gut. Nat Med. 2008; 14:421-428. [PubMed: 18376406]

219. Wang X, Das A, Lackner AA, Veazey RS, Pahar B. Intestinal double-positive CD4+CD8+ T cells of neonatal rhesus macaques are proliferating, activated memory cells and primary targets for SIVMAC251 infection. Blood. 2008; 112:4981-4990. [PubMed: 18820133]

220. Wang X, et al. Simian immunodeficiency virus selectively infects proliferating CD4+ T cells in neonatal rhesus macaques. Blood. 2010; 116:4168-4174. [PubMed: 20716768]

221. Nanthakumar NN, Fusunyan RD, Sanderson I, Walker WA. Inflammation in the developing human intestine: A possible pathophysiologic contribution to necrotizing enterocolitis. Proc Natl Acad Sci USA. 2000; 97:6043-6048. [PubMed: 10823949]

222. Siberry GK, et al. Increased risk of asthma and atopic dermatitis in perinatally HIV-infected children and adolescents. Clin Immunol. 2012; 142:201-208. [PubMed: 22094294]

223. Foster SB, et al. Increased incidence of asthma in HIV-infected children treated with highly active antiretroviral therapy in the National Institutes of Health Women and Infants Transmission Study. J Allergy Clin Immunol. 2008; 122:159-165. [PubMed: 18547627]

224. Papasavvas E, et al. Increased microbial translocation in $</=180$ days old perinatally human immunodeficiency virus-positive infants as compared with human immunodeficiency virusexposed uninfected infants of similar age. Ped Infect Dis J. 2011; 30:877-882.

225. Wallet MA, et al. Microbial translocation induces persistent macrophage activation unrelated to HIV-1 levels or T-cell activation following therapy. AIDS. 2010; 24:1281-1290. [PubMed: 20559035]

226. Tozzi AE, Pezzotti P, Greco D. Does breast-feeding delay progression to AIDS in HIV-infected children? AIDS. 1990; 4:1293-1294. [PubMed: 2088407]

227. Kafulafula G, et al. Frequency of gastroenteritis and gastroenteritis-associated mortality with early weaning in HIV-1-uninfected children born to HIV-infected women in Malawi. J Acquir Immune Defic Syndr. 2010; 53:6-13. [PubMed: 19844183]

228. Taha TE, et al. Effects of cessation of breastfeeding in HIV-1-exposed, uninfected children in Malawi. Clin Infect Dis. 2011; 53:388-395. [PubMed: 21810754] 
229. Onyango-Makumbi C, et al. Early weaning of HIV-exposed uninfected infants and risk of serious gastroenteritis: findings from two perinatal HIV prevention trials in Kampala, Uganda. J Acquir Immune Defic Syndr. 2010; 53:20-27.

230. Homsy J, et al. Breastfeeding, mother-to-child HIV transmission, and mortality among infants born to HIV-Infected women on highly active antiretroviral therapy in rural Uganda. J Acquir Immune Defic Syndr. 2010; 53:28-35. [PubMed: 19797972]

231. Kagaayi J, et al. Survival of infants born to HIV-positive mothers by feeding modality in Rakai, Uganda. PLOS One. 2008; 3:e3877. [PubMed: 19065270]

232. Nduati R, et al. Effect of breastfeeding and formula feeding on transmission of HIV-1: a randomized clinical trial. JAMA. 2000; 283:1167-1174. [PubMed: 10703779]

233. Thior I, et al. Breastfeeding plus infant zidovudine prophylaxis for 6 months vs formula feeding plus infant zidovudine for 1 month to reduce mother-to-child HIV transmission in Botswana: a randomized trial: the Mashi Study. JAMA. 2006; 296:794-805. [PubMed: 16905785]

234. Kuhn L, et al. Elevations in mortality associated with weaning persist into the second year of life among uninfected children born to HIV-infected mothers. Clin Infect Dis. 2010; 50:437-444. [PubMed: 20047479]

235. Kuhn L, et al. Differential effects of early weaning for HIV-free survival of children born to HIVinfected mothers by severity of maternal disease. PloS One. 2009; 4:e6059. [PubMed: 19557167]

236. Kafulafula G, et al. Frequency of gastroenteritis and gastroenteritis-associated mortality with early weaning in HIV-1-uninfected children born to HIV-infected women in Malawi. J Acq Imm Def Syndr. 2010; 53:6-13.

237. Harris JR, et al. Effect of a point-of-use water treatment and safe water storage intervention on diarrhea in infants of HIV-infected mothers. J Infect Dis. 2009; 200:1186-1193. [PubMed: 19758095]

238. Onyango-Makumbi C, et al. Early weaning of HIV-exposed uninfected infants and risk of serious gastroenteritis: findings from two perinatal HIV prevention trials in Kampala, Uganda. J Acuir Immun Defic Syndr. 2009

239. Becquet R, et al. Two-year morbidity-mortality and alternatives to prolonged breast-feeding among children born to HIV-infected mothers in Cote d'Ivoire. PLoS Med. 2007; 4:e17. [PubMed: 17227132]

240. Doherty T, Chopra M, Jackson D, Goga A, Colvin M, Persson LA. Effectiveness of the WHO/ UNICEF guidelines on infant feeding for HIV-positive women: results from a prospective cohort study in South Africa. AIDS. 2007; 21:1791-1797. [PubMed: 17690578]

241. Kagaayi J, et al. Survival of infants born to HIV-positive mothers, by feeding modality, in Rakai, Uganda. PloS One. 2008; 3:e3877. [PubMed: 19065270]

242. Homsy J, et al. Breastfeeding, mother-to-child HIV transmission, and mortality among infants born to HIV-Infected women on highly active antiretroviral therapy in rural Uganda. J Acquir Immun Defic Syndr. 2010; 53:28-35.

243. Peltier CA, et al. Breastfeeding with maternal antiretroviral therapy or formula feeding to prevent HIV postnatal mother-to-child transmission in Rwanda. AIDS. 2009; 23:2415-2423. [PubMed: 19730349]

244. Nyandiko WM, et al. Outcomes of HIV-exposed children in western Kenya: efficacy of prevention of mother to child transmission in a resource-constrained setting. J Acquir Immun Defic Syndr. 2010; 54:42-50.

245. Phadke MA, et al. Replacement-fed infants born to HIV-infected mothers in India have a high early postpartum rate of hospitalization. J Nutr. 2003; 133:3153-3157. [PubMed: 14519801]

246. Taha TE, et al. The impact of breastfeeding on the health of HIV-positive mothers and their children in sub-Saharan Africa. Bull World Health Organization. 2006; 84:546-554.

247. Creek TL, et al. Hospitalization and mortality among primarily nonbreastfed children during a large outbreak of diarrhea and malnutrition in Botswana, 2006. J Acquir Immun Defic Syndr. 2010; 53:14-19.

248. Kuhn L, Aldrovandi G. Pendulum swings in HIV-1 and infant feeding policies: now halfway back. Adv Exp Med Biol. 2012; 743:273-287. [PubMed: 22454357] 
249. Brahmbhatt $\mathrm{H}$, et al. Mortality in HIV-infected and uninfected children of HIV-infected and uninfected mothers in rural Uganda. J Acquir Immun Defic Syndr. 2006; 41:504-508.

250. Newell ML, Coovadia H, Cortina-Borja M, Rollins N, Gaillard P, Dabis F. Mortality of infected and uninfected infants born to HIV-infected mothers in Africa: a pooled analysis. Lancet. 2004; 364:1236-1243. [PubMed: 15464184]

251. Chatterjee A, Bosch RJ, Hunter DJ, Fataki MR, Msamanga GI, Fawzi WW. Maternal disease stage and child undernutrition in relation to mortality among children born to HIV-infected women in Tanzania. J Acquir Immun Defic Syndr. 2007; 46:599-606.

252. Gichuhi C, et al. Predictors of mortality in HIV-1 exposed uninfected post-neonatal infants at the Kenyatta National Hospital, Nairobi. East African Med J. 2005; 82:447-451.

253. Chilongozi D, et al. Morbidity and mortality among a cohort of human immunodeficiency virus type 1-infected and uninfected pregnant women and their infants from Malawi, Zambia, and Tanzania. Ped Infect Dis J. 2008; 27:808-814.

254. Shapiro RL, et al. Infant morbidity, mortality, and breast milk immunologic profiles among breast-feeding HIV-infected and HIV-uninfected women in Botswana. J Infect Dis. 2007; 196:562-569. [PubMed: 17624842]

255. Castelletti E, et al. The mucosae-associated epithelial chemokine (MEC/CCL28) modulates immunity in HIV infection. PloS One. 2007; 2:e969. [PubMed: 17912348]

256. Dauby N, Goetghebuer T, Kollmann TR, Levy J, Marchant A. Uninfected but not unaffected: chronic maternal infections during pregnancy, fetal immunity, and susceptibility to postnatal infections. Lancet Infect Dis. 2012; 12:330-340. [PubMed: 22364680]

257. Kuhn L, Thea DM, Aldrovandi GM. Bystander effects: children who escape infection but not harm. J Acquir Immun Defic Syndr. 2007; 46:517-518.

258. Hygino J, et al. Altered immunological reactivity in HIV-1-exposed uninfected neonates. Clin Immunol. 2008; 127:340-347. [PubMed: 18356112]

259. Chougnet $C$, et al. Influence of human immunodeficiency virus-infected maternal environment on development of infant interleukin-12 production. J Infect Dis. 2000; 181:1590-1597. [PubMed: 10823758]

260. Epalza C, et al. High incidence of invasive group B streptococcal infections in HIV-exposed uninfected infants. Pediatrics. 2010; 126:e631-e638. [PubMed: 20732944]

261. Miyamoto M, et al. Low CD4+ T-cell levels and B-cell apoptosis in vertically HIV-exposed noninfected children and adolescents. J Trop Ped. 2010; 56:427-432.

262. Ono E, et al. Imbalance of naive and memory T lymphocytes with sustained high cellular activation during the first year of life from uninfected children born to HIV-1-infected mothers on HAART. Brazilian J Med Biol Res. 2008; 41:700-708.

263. Slogrove AL, Cotton MF, Esser MM. Severe infections in HIV-exposed uninfected infants: clinical evidence of immunodeficiency. J Trop Ped. 2010; 56:75-81.

264. Van Rie A, et al. Gamma interferon production in response to Mycobacterium bovis BCG and Mycobacterium tuberculosis antigens in infants born to human immunodeficiency virus-infected mothers. Clin Vaccine Immunol. 2006; 13:246-252. [PubMed: 16467333]

265. Gesner M, et al. Alteration in the proportion of CD4 T lymphocytes in a subgroup of human immunodeficiency virus-exposed-uninfected children. Pediatrics. 1994; 93:624-630. [PubMed: 8134219]

266. Nielsen SD, et al. Impaired progenitor cell function in HIV-negative infants of HIV-positive mothers results in decreased thymic output and low CD4 counts. Blood. 2001; 98:398-404. [PubMed: 11435309]

267. Clerici M, et al. T-lymphocyte maturation abnormalities in uninfected newborns and children with vertical exposure to HIV. Blood. 2000; 96:3866-3871. [PubMed: 11090071]

268. Rich KC, Siegel JN, Jennings C, Rydman RJ, Landay AL. Function and phenotype of immature CD4+ lymphocytes in healthy infants and early lymphocyte activation in uninfected infants of human immunodeficiency virus-infected mothers. Clin Diagnost Lab Immunol. 1997; 4:358-361.

269. Economides A, Schmid I, Anisman-Posner DJ, Plaeger S, Bryson YJ, Uittenbogaart CH. Apoptosis in cord blood T lymphocytes from infants of human immunodeficiency virus-infected mothers. Clin Diagnost Lab Immunol. 1998; 5:230-234. 
270. Miles DJ, Gadama L, Gumbi A, Nyalo F, Makanani B, Heyderman RS. Human immunodeficiency virus (HIV) infection during pregnancy induces CD4 T-cell differentiation and modulates responses to Bacille Calmette-Guerin (BCG) vaccine in HIV-uninfected infants. Immunology. 2010; 129:446-454. [PubMed: 20002789]

271. Harari A, Petitpierre S, Vallelian F, Pantaleo G. Skewed representation of functionally distinct populations of virus-specific CD4 T cells in HIV-1-infected subjects with progressive disease: changes after antiretroviral therapy. Blood. 2004; 103:966-972. [PubMed: 12958069]

272. Velilla PA, Montoya CJ, Hoyos A, Moreno ME, Chougnet C, Rugeles MT. Effect of intrauterine HIV-1 exposure on the frequency and function of uninfected newborns' dendritic cells. Clin Immunol. 2008; 126:243-250. [PubMed: 18201932]

273. Embree J, et al. Lymphocyte subsets in human immunodeficiency virus type 1-infected and uninfected children in Nairobi. Ped Infect Dis J. 2001; 20:397-403.

274. Kuhn L, et al. Interferon-gamma and interleukin-10 production among HIV-1-infected and uninfected infants of HIV-1-infected mothers. Ped Res. 2001; 50:412-416.

275. Jones CE, Naidoo S, De Beer C, Esser M, Kampmann B, Hesseling AC. Maternal HIV infection and antibody responses against vaccine-preventable diseases in uninfected infants. JAMA. 2011; 305:576-584. [PubMed: 21304083]

276. Mansoor N, et al. HIV-1 infection in infants severely impairs the immune response induced by Bacille Calmette-Guerin vaccine. J Infect Dis. 2009; 199:982-990. [PubMed: 19236280]

277. Helfand RF, et al. Evaluation of the immune response to a 2-dose measles vaccination schedule administered at 6 and 9 months of age to HIV-infected and HIV-uninfected children in Malawi. J Infect Dis. 2008; 198:1457-1465. [PubMed: 18828743]

278. Abramczuk BM, et al. Impaired humoral response to vaccines among HIV-exposed uninfected infants. Clin Vaccine Immunol. 2011; 18:1406-1409. [PubMed: 21775515]

279. Mazzola TN, et al. Impaired Bacillus Calmette-Guerin cellular immune response in HIV-exposed, uninfected infants. AIDS. 2011; 25:2079-2087. [PubMed: 21866040]

280. de Moraes-Pinto MI, et al. Placental transfer and maternally acquired neonatal IgG immunity in human immunodeficiency virus infection. J Infect Dis. 1996; 173:1077-1084. [PubMed: 8627057]

281. Farquhar C, et al. High maternal HIV-1 viral load during pregnancy is associated with reduced placental transfer of measles IgG antibody. J Acquir Immun Defic Syndr. 2005; 40:494-497.

282. Kuhn L, et al. Does severity of HIV disease in HIV-infected mothers affect mortality and morbidity among their uninfected infants? Clin Infect Dis. 2005; 41:1654-1661. [PubMed: 16267740]

283. Thea DM, et al. A prospective study of diarrhea and HIV-1 infection among 429 Zairian infants. N Engl J Med. 1993; 329:1696-1702. [PubMed: 8232458]

284. McNally LM, et al. Effect of age, polymicrobial disease, and maternal HIV status on treatment response and cause of severe pneumonia in South African children: a prospective descriptive study. Lancet. 2007; 369:1440-1451. [PubMed: 17467514]

285. Heresi GP, Caceres E, Atkins JT, Reuben J, Doyle M. Pneumocystis carinii pneumonia in infants who were exposed to human immunodeficiency virus but were not infected: an exception to the AIDS surveillance case definition. Clin Infect Dis. 1997; 25:739-740. [PubMed: 9314473]

286. Mussi-Pinhata MM, et al. Lower respiratory tract infections among human immunodeficiency virus-exposed, uninfected infants. Int J Infect Dis. 2010; 14(Suppl):e176-e182. [PubMed: 20452798]

287. Mussi-Pinhata MM, et al. Infectious disease morbidity among young HIV-1-exposed but uninfected infants in Latin American and Caribbean countries: the National Institute of Child Health and Human Development International Site Development Initiative Perinatal Study. Pediatrics. 2007; 119:e694-e704. [PubMed: 17296782]

288. Bamji M, et al. Prospective study of human immunodeficiency virus 1-related disease among 512 infants born to infected women in New York City. The New York City Perinatal HIV Transmission Collaborative Study Group. Ped Infect Dis J. 1996; 15:891-898. 
289. Paul ME, et al. Morbidity and mortality during the first two years of life among uninfected children born to human immunodeficiency virus type 1-infected women: the women and infants transmission study. Ped Infect Dis J. 2005; 24:46-56.

290. Lepage P, et al. Growth of human immunodeficiency type 1-infected and uninfected children: a prospective cohort study in Kigali, Rwanda, 1988 to 1993. Ped Infect Dis J. 1996; 15:479-485.

291. Kjetland EF, et al. Association between genital schistosomiasis and HIV in rural Zimbabwean women. AIDS. 2006; 20:593-600. [PubMed: 16470124]

292. De Milito A, Morch C, Sonnerborg A, Chiodi F. Loss of memory (CD27) B lymphocytes in HIV-1 infection. AIDS. 2001; 15:957-964. [PubMed: 11399977]

293. Keating SM, et al. The effect of HIV infection and HAART on inflammatory biomarkers in a population-based cohort of women. AIDS. 2011; 25:1823-1832. [PubMed: 21572306]

294. Jacobson MA, Khayam-Bashi H, Martin JN, Black D, Ng V. Effect of long-term highly active antiretroviral therapy in restoring HIV-induced abnormal B-lymphocyte function. J Acquir Immun Defic Syndr. 2002; 31:472-477.

295. Redgrave BE, Stone SF, French MA, Krueger R, James IR, Price P. The effect of combination antiretroviral therapy on CD5 B- cells, B-cell activation and hypergammaglobulinaemia in HIV-1-infected patients. HIV Med. 2005; 6:307-312. [PubMed: 16156877]

296. Klugman KP, Madhi SA, Feldman C. HIV and pneumococcal disease. Curr Opin Infect Dis. 2007; 20:11-15. [PubMed: 17197876]

297. Harries AD, et al. The HIV-associated tuberculosis epidemic--when will we act? Lancet. 2010; 375:1906-1919. [PubMed: 20488516]

298. O'Brien KL, et al. Burden of disease caused by Streptococcus pneumoniae in children younger than 5 years: global estimates. Lancet. 2009; 374:893-902. [PubMed: 19748398]

299. Mathers, C.; Fat, DM.; Boerma, JT. World Health Organization. Geneva, Switzerland: World Health Organization; 2008. The global burden of disease : 2004 update.

300. Perez-Velez CM, Marais BJ. Tuberculosis in children. N Engl J Med. 2012; 367:348-361. [PubMed: 22830465]

301. Regidor DL, et al. Effect of highly active antiretroviral therapy on biomarkers of B-lymphocyte activation and inflammation. AIDS. 2011; 25:303-314. [PubMed: 21192231]

302. Abel K. The rhesus macaque pediatric SIV infection model - a valuable tool in understanding infant HIV-1 pathogenesis and for designing pediatric HIV-1 prevention strategies. Curr HIV Res. 2009; 7:2-11. [PubMed: 19149549]

303. Abel K, et al. Rapid virus dissemination in infant macaques after oral simian immunodeficiency virus exposure in the presence of local innate immune responses. J Virol. 2006; 80:6357-6367. [PubMed: 16775324]

304. Amedee AM, Lacour N, Ratterree M. Mother-to-infant transmission of SIV via breast-feeding in rhesus macaques. J Med Primatol. 2003; 32:187-193. [PubMed: 14498978]

305. Amedee AM, Rychert J, Lacour N, Fresh L, Ratterree M. Viral and immunological factors associated with breast milk transmission of SIV in rhesus macaques. Retrovirology. 2004; 1:17. [PubMed: 15253769]

306. Davison-Fairburn B, et al. Experimental infection of timed-pregnant rhesus monkeys with simian immunodeficiency virus (SIV) during early, middle, and late gestation. J Med Primatol. 1990; 19:381-393. [PubMed: 2231690]

307. Jayaraman P, et al. Perinatal transmission of SHIV-SF162P3 in Macaca nemestrina. J Med Primatol. 2004; 33:243-250. [PubMed: 15525325]

308. Marthas ML, et al. Viral factors determine progression to AIDS in simian immunodeficiency virus-infected newborn rhesus macaques. J Virol. 1995; 69:4198-4205. [PubMed: 7769679]

309. McClure HM, Anderson DC, Ansari AA, Klumpp SA. The simian immunodeficiency virus infected macaque: a model for pediatric AIDS. Pathologiebiologie. 1992; 40:694-700.

310. McClure HM, et al. Maternal transmission of SIVsmm in rhesus macaques. J Med Primatol. 1991; 20:182-187. [PubMed: 1942008]

311. Ochs HD, et al. Intra-amniotic inoculation of pigtailed macaque (Macaca nemestrina) fetuses with SIV and HIV-1. J Med Primatol. 1993; 22:162-168. [PubMed: 8411108] 
312. Jayaraman $\mathrm{P}$, et al. Evidence for persistent, occult infection in neonatal macaques following perinatal transmission of simian-human immunodeficiency virus SF162P3. J Virol. 2007; 81:822-834. [PubMed: 17079310]

313. Hartigan-O'Connor DJ, Abel K, McCune JM. Suppression of SIV-specific CD4+ T cells by infant but not adult macaque regulatory T cells: implications for SIV disease progression. J Exp Med. 2007; 204:2679-2692. [PubMed: 17954571]

314. Ortiz AM, et al. Depletion of CD4(+) T cells abrogates post-peak decline of viremia in SIVinfected rhesus macaques. J Clin Invest. 2011; 121:4433-4445. [PubMed: 22005304]

315. Wang X, et al. Massive infection and loss of CD4+ T cells occurs in the intestinal tract of neonatal rhesus macaques in acute SIV infection. Blood. 2007; 109:1174-1181. [PubMed: 17047153]

316. Milush JM, et al. Rapid dissemination of SIV following oral inoculation. AIDS. 2004; 18:23712380. [PubMed: 15622313]

317. Veazey RS, Lifson JD, Pandrea I, Purcell J, Piatak M Jr, Lackner AA. Simian immunodeficiency virus infection in neonatal macaques. J Virol. 2003; 77:8783-8792. [PubMed: 12885897]

318. McChesney MB, et al. Occult systemic infection and persistent simian immunodeficiency virus (SIV)-specific CD4(+)-T-cell proliferative responses in rhesus macaques that were transiently viremic after intravaginal inoculation of SIV. J Virol. 1998; 72:10029-10035. [PubMed: 9811741]

319. Trivedi $\mathrm{P}$, et al. Intrarectal transmission of simian immunodeficiency virus in rhesus macaques: selective amplification and host responses to transient or persistent viremia. J Virol. 1996; 70:6876-6883. [PubMed: 8794330]

320. Van Rompay KK, et al. Passive immunization of newborn rhesus macaques prevents oral simian immunodeficiency virus infection. J Infect Dis. 1998; 177:1247-1259. [PubMed: 9593009]

321. Deborah, Persaud HG.; Ziemniak, Carrie; Chen, Ya Hui; Piatak, Michael, Jr; Chun, Tae-Wook; Strain, Matthew; Richman, Douglas; Luzuriaga, Katherine. Functional HIV Cure after Very Early Antiretroviral Therapy of an Infected Infant. 2013 Conference on Retroviruses and Opportunistic Infections; March 3-6, 2013; Atlanta, GA. 2013.

322. Silvestri G, et al. Nonpathogenic SIV infection of sooty mangabeys is characterized by limited bystander immunopathology despite chronic high-level viremia. Immunity. 2003; 18:441-452. [PubMed: 12648460]

323. Apetrei $\mathrm{C}$, et al. Immunovirological analyses of chronically simian immunodeficiency virus SIVmnd-1- and SIVmnd-2-infected mandrills (Mandrillus sphinx). J Virol. 2011; 85:1307713087. [PubMed: 21957286]

324. Goldstein S, et al. Comparison of simian immunodeficiency virus SIVagmVer replication and CD4+ T-cell dynamics in vervet and sabaeus African green monkeys. J Virol. 2006; 80:48684877. [PubMed: 16641278]

325. Rey-Cuille MA, et al. Simian immunodeficiency virus replicates to high levels in sooty mangabeys without inducing disease. J Virol. 1998; 72:3872-3886. [PubMed: 9557672]

326. Pandrea I, et al. Simian immunodeficiency viruses replication dynamics in African non-human primate hosts: common patterns and species-specific differences. J Med Primatol. 2006; 35:194201. [PubMed: 16872282]

327. Worobey M, et al. Island biogeography reveals the deep history of SIV. Science. 2010; 329:1487. [PubMed: 20847261]

328. VandeWoude S, Apetrei C. Going wild: lessons from naturally occurring T-lymphotropic lentiviruses. Clin Microbiol Med. 2006; 19:728-762.

329. Pandrea I, et al. Paucity of CD4+ CCR5+ T cells may prevent transmission of simian immunodeficiency virus in natural nonhuman primate hosts by breast-feeding. J Virol. 2008; 82:5501-5509. [PubMed: 18385229]

330. Chahroudi A, Meeker T, Lawson B, Ratcliffe S, Else J, Silvestri G. Mother-to-infant transmission of simian immunodeficiency virus is rare in sooty mangabeys and is associated with low viremia. J Virol. 2011; 85:5757-5763. [PubMed: 21450815]

331. Otsyula MG, Gettie A, Suleman M, Tarara R, Mohamed I, Marx P. Apparent lack of vertical transmission of simian immunodeficiency virus (SIV) in naturally infected African green 
monkeys, Cercopithecus aethiops. Ann Trop Med Parasitol. 1995; 89:573-576. [PubMed: 7495371]

332. Violari A, et al. Early antiretroviral therapy and mortality among HIV-infected infants. N Engl J Med. 2008; 359:2233-2244. [PubMed: 19020325]

333. Essajee SM, et al. Immunologic and virologic responses to HAART in severely immunocompromised HIV-1-infected children. AIDS. 1999; 13:2523-2532. [PubMed: 10630521]

334. Ghaffari G, Passalacqua DJ, Caicedo JL, Goodenow MM, Sleasman JW. Two-year clinical and immune outcomes in human immunodeficiency virus-infected children who reconstitute CD4 T cells without control of viral replication after combination antiretroviral therapy. Pediatrics. 2004; 114:e604-e611. [PubMed: 15492356]

335. Soh CH, et al. Long-term effects of protease-inhibitor-based combination therapy on CD4 T-cell recovery in HIV-1-infected children and adolescents. Lancet. 2003; 362:2045-2051. [PubMed: 14697803]

336. Walker AS, Doerholt K, Sharland M, Gibb DM. Response to highly active antiretroviral therapy varies with age: the UK and Ireland Collaborative HIV Paediatric Study. AIDS. 2004; 18:19151924. [PubMed: 15353977]

337. Weinberg A, et al. Continuous improvement in the immune system of HIV-infected children on prolonged antiretroviral therapy. AIDS. 2008; 22:2267-2277. [PubMed: 18981766]

338. Resino S, Seoane E, Perez A, Ruiz-Mateos E, Leal M, Munoz-Fernandez MA. Different profiles of immune reconstitution in children and adults with HIV-infection after highly active antiretroviral therapy. BMC Infect Dis. 2006; 6:112. [PubMed: 16839416]

339. Luzuriaga K, McManus M, Mofenson L, Britto P, Graham B, Sullivan JL. A trial of three antiretroviral regimens in HIV-1-infected children. N Engl J Med. 2004; 350:2471-2480. [PubMed: 15190139]

340. Feeney ME, et al. Reconstitution of virus-specific CD4 proliferative responses in pediatric HIV-1 infection. J Immunol. 2003; 171:6968-6975. [PubMed: 14662905]

341. Lee JC, et al. Thymic volume, T-cell populations, and parameters of thymopoiesis in adolescent and adult survivors of HIV infection acquired in infancy. AIDS. 2006; 20:667-674. [PubMed: 16514296]

342. Mackall CL, et al. Age, thymopoiesis, and CD4+ T-lymphocyte regeneration after intensive chemotherapy. N Engl J Med. 1995; 332:143-149. [PubMed: 7800006]

343. Shiau S, et al. Initiation of Antiretroviral Therapy Before 6 Months of Age is Associated with Faster Growth Recovery in South African Children Perinatally Infected with Human Immunodeficiency Virus. J Ped. 2013

344. Laughton B, et al. Early antiretroviral therapy improves neurodevelopmental outcomes in infants. AIDS. 2012; 26:1685-1690. [PubMed: 22614886]

345. Penazzato M, Prendergast A, Tierney J, Cotton M, Gibb D. Effectiveness of antiretroviral therapy in HIV-infected children under 2 years of age. Cochrane Database Syst Rev. 2012; 7 CD004772.

346. Wamalwa D, et al. Survival benefit of early infant antiretroviral therapy is compromised when diagnosis is delayed. Ped Infect Dis J. 2012; 31:729-731.

347. Goetghebuer T, et al. Short- and long-term immunological and virological outcome in HIVinfected infants according to the age at antiretroviral treatment initiation. Clin Infect Dis. 2012; 54:878-881. [PubMed: 22198788]

348. Goetghebuer T, et al. Effect of early antiretroviral therapy on the risk of AIDS/death in HIVinfected infants. AIDS. 2009; 23:597-604. [PubMed: 19194272]

349. Puthanakit T, et al. Early versus deferred antiretroviral therapy for children older than 1 year infected with HIV (PREDICT): a multicentre, randomised, open-label trial. Lancet Infect Dis. 2012; 12:933-941. [PubMed: 23059199]

350. Puthanakit T, et al. Cognitive Function and Neurodevelopmental Outcomes in HIV-Infected Children Older than 1 Year of Age Randomized to Early Versus Deferred Antiretroviral Therapy: The PREDICT Neurodevelopmental Study. Ped Infect Dis J. 2013 
351. Archin NM, et al. Immediate antiviral therapy appears to restrict resting CD4+ cell HIV-1 infection without accelerating the decay of latent infection. Proc Natl Acad Sci USA. 2012; 109:9523-9528. [PubMed: 22645358]

352. Holte SE, Melvin AJ, Mullins JI, Tobin NH, Frenkel LM. Density-dependent decay in HIV-1 dynamics. J Acquir Immun Defic Syndr. 2006; 41:266-276.

353. Siliciano JD, et al. Long-term follow-up studies confirm the stability of the latent reservoir for HIV-1 in resting CD4+ T cells. Nat Med. 2003; 9:727-728. [PubMed: 12754504]

354. Ramratnam B, et al. The decay of the latent reservoir of replication-competent HIV-1 is inversely correlated with the extent of residual viral replication during prolonged anti-retroviral therapy. Nat Med. 2000; 6:82-85. [PubMed: 10613829]

355. Finzi D, et al. Latent infection of CD4+ T cells provides a mechanism for lifelong persistence of HIV-1, even in patients on effective combination therapy. Nat Med. 1999; 5:512-517. [PubMed: 10229227]

356. Finzi D, et al. Identification of a reservoir for HIV-1 in patients on highly active antiretroviral therapy. Science. 1997; 278:1295-1300. [PubMed: 9360927]

357. Blankson JN, Persaud D, Siliciano RF. The challenge of viral reservoirs in HIV-1 infection. Annu Rev Med. 2002; 53:557-593. [PubMed: 11818490]

358. Persaud D, et al. A stable latent reservoir for HIV-1 in resting CD4(+) T lymphocytes in infected children. J Clin Invest. 2000; 105:995-1003. [PubMed: 10749578]

359. Ruff CT, et al. Persistence of wild-type virus and lack of temporal structure in the latent reservoir for human immunodeficiency virus type 1 in pediatric patients with extensive antiretroviral exposure. J Virol. 2002; 76:9481-9492. [PubMed: 12186930]

360. Persaud D, et al. Dynamics of the resting CD4(+) T-cell latent HIV reservoir in infants initiating HAART less than 6 months of age. AIDS. 2012; 26:1483-1490. [PubMed: 22555165]

361. Katherine Luzuriaga, YHC.; Ziemniak, Carrie; Siberry, George K.; Strain, Matt; Richman, Douglas; Chun, Tae-Wook; Cunningham, Coleen; Persaud, Deborah. Absent HIV-Specific Immune Responses and Replication-Competent HIV-Reservoirs in Perinatally-Infected Youth treated from Infancy: Towards Cure. 2013 Conference on Retroviruses and Opportunistic Infections; March 3-6, 2013; Atlanta, GA. 2013.

362. Van Rompay KK, et al. Prolonged tenofovir treatment of macaques infected with K65R reverse transcriptase mutants of SIV results in the development of antiviral immune responses that control virus replication after drug withdrawal. Retrovirology. 2012; 9:57. [PubMed: 22805180]

363. Frenkel LM, et al. Genetic evaluation of suspected cases of transient HIV-1 infection of infants. Science. 1998; 280:1073-1077. [PubMed: 9582120]

364. Hartigan-O'Connor DJ, Abel K, Van Rompay KK, Kanwar B, McCune JM. SIV replication in the infected rhesus macaque is limited by the size of the preexisting TH17 cell compartment. Sci Trans Med. 2012; 4:136ra169.

365. Le T, et al. Enhanced CD4+ T-cell recovery with earlier HIV-1 antiretroviral therapy. N Engl J Med. 2013; 368:218-230. [PubMed: 23323898]

366. Fidler S, et al. Short-course antiretroviral therapy in primary HIV infection. N Engl J Med. 2013; 368:207-217. [PubMed: 23323897]

367. Deeks SG, et al. Towards an HIV cure: a global scientific strategy. Nature reviews Immunology. 2012; 12:607-614.

368. Magder LS, et al. Risk factors for in utero and intrapartum transmission of HIV. J Acquir Immun Defic Syndr. 2005; 38:87-95.

369. Mofenson LM, et al. Risk factors for perinatal transmission of human immunodeficiency virus type 1 in women treated with zidovudine. Pediatric AIDS Clinical Trials Group Study 185 Team. N Engl J Med. 1999; 341:385-393. [PubMed: 10432323]

370. Bulterys PL, et al. Placental malaria and mother-to-child transmission of human immunodeficiency virus-1 in rural Rwanda. Am J Trop Med Hygeine. 2011; 85:202-206.

371. Panther LA, Tucker L, Xu C, Tuomala RE, Mullins JI, Anderson DJ. Genital tract human immunodeficiency virus type 1 (HIV-1) shedding and inflammation and HIV-1 env diversity in perinatal HIV-1 transmission. J Infect Dis. 2000; 181:555-563. [PubMed: 10669339] 
372. Ricci E, et al. Toll-like receptor 9 polymorphisms influence mother-to-child transmission of human immunodeficiency virus type 1. J Trans Med. 2010; 8:49.

373. Torres G, Garcia V, Sanchez E, Segarra A, Patterson BK, Melendez-Guerrero LM. Expression of the HIV-1 co-receptors CCR5 and CXCR4 on placental macrophages and the effect of IL-10 on their expression. Placenta. 2001; 22(Suppl):S29-S33. [PubMed: 11312625]

374. Henrick BM, Nag K, Yao XD, Drannik AG, Aldrovandi GM, Rosenthal KL. Milk matters: soluble Toll-like receptor 2 (sTLR2) in breast milk significantly inhibits HIV-1 infection and inflammation. PloS One. 2012; 7:e40138. [PubMed: 22792230]

375. Spector SA. Mother-to-infant transmission of HIV-1: the placenta fights back. J Clin Invest. 2001; 107:267-269. [PubMed: 11160148]

376. Ricci E, Malacrida S, Zanchetta M, Montagna M, Giaquinto C, De Rossi A. Role of betadefensin-1 polymorphisms in mother-to-child transmission of HIV-1. J Acquir Immun Defic Syndr. 2009; 51:13-19. 


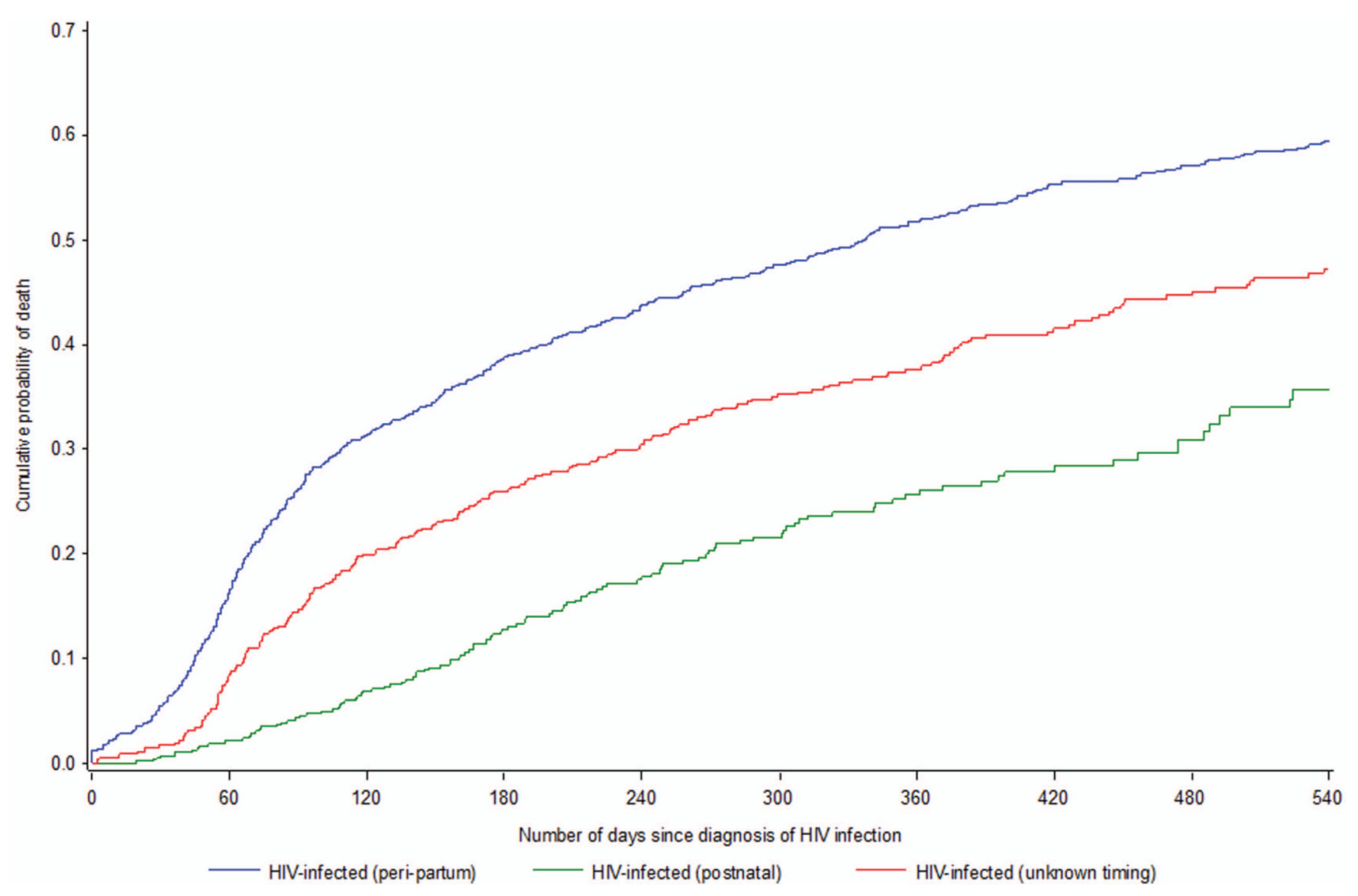

Fig. 1. Estimated 18-month unadjusted mortality for HIV-infected children since acquisition of HIV infection $\mathrm{n}=2$,509. from Becquet $\mathrm{R}$ et al. (99). demonstrating profound mortality differences between peri-partum and postnatal acquisition ( $52 \%$ versus $26 \%$ at 1 year). 




Fig. 2. Survival in breastfed versus bottle-fed HIV-infected infants

(A) Survival to 36 months among HIV-infected infants from diagnosis by type of feeding, 64 bottle fed infants (dotted line) versus 36 breast-fed infants (solid line) from the Italian National Registry of AIDS through February 1990 (Breslow p=0.01; Mantel-Cox p=0.003) from Tozzi et al. (240). (B) Survival to 24 months among children who had HIV infection by 4 months of age ( 71 children assigned to abrupt weaning at 4 months and 81 assigned to the control group of standard breastfeeding practices with median duration of breastfeeding of 16 months) from a controlled trial in Zambia $(p=0.007)$ from Kuhn et al $(40)$. 


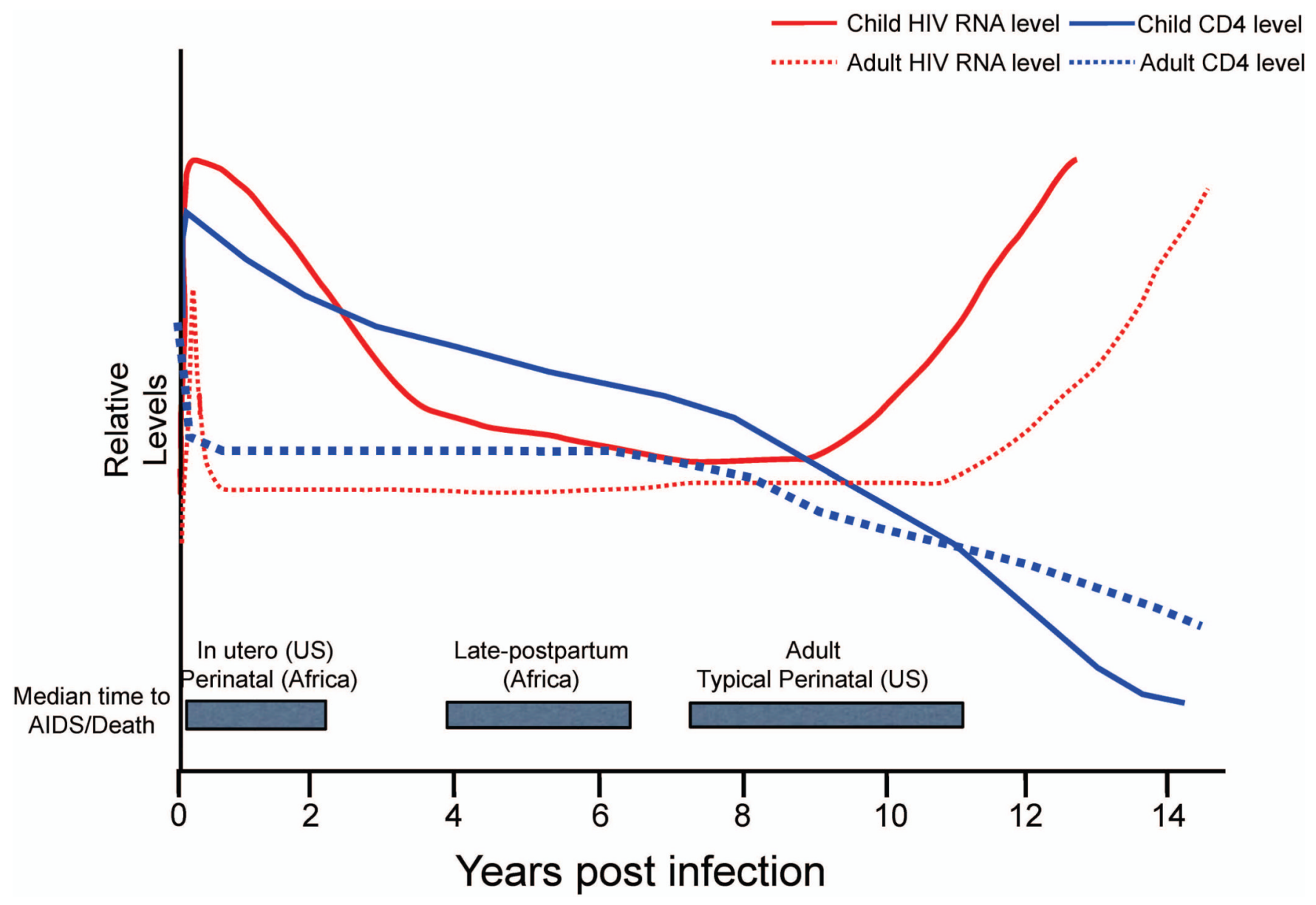

Fig. 3. Relative levels of HIV RNA (red) and CD4 cells (blue) in adults (dotted lines) and children (solid lines) in the years following acquisition of HIV-1

Gray boxes highlight the median time to AIDS/Death for infants by region and route of infection in comparison to adults. US - United States. 

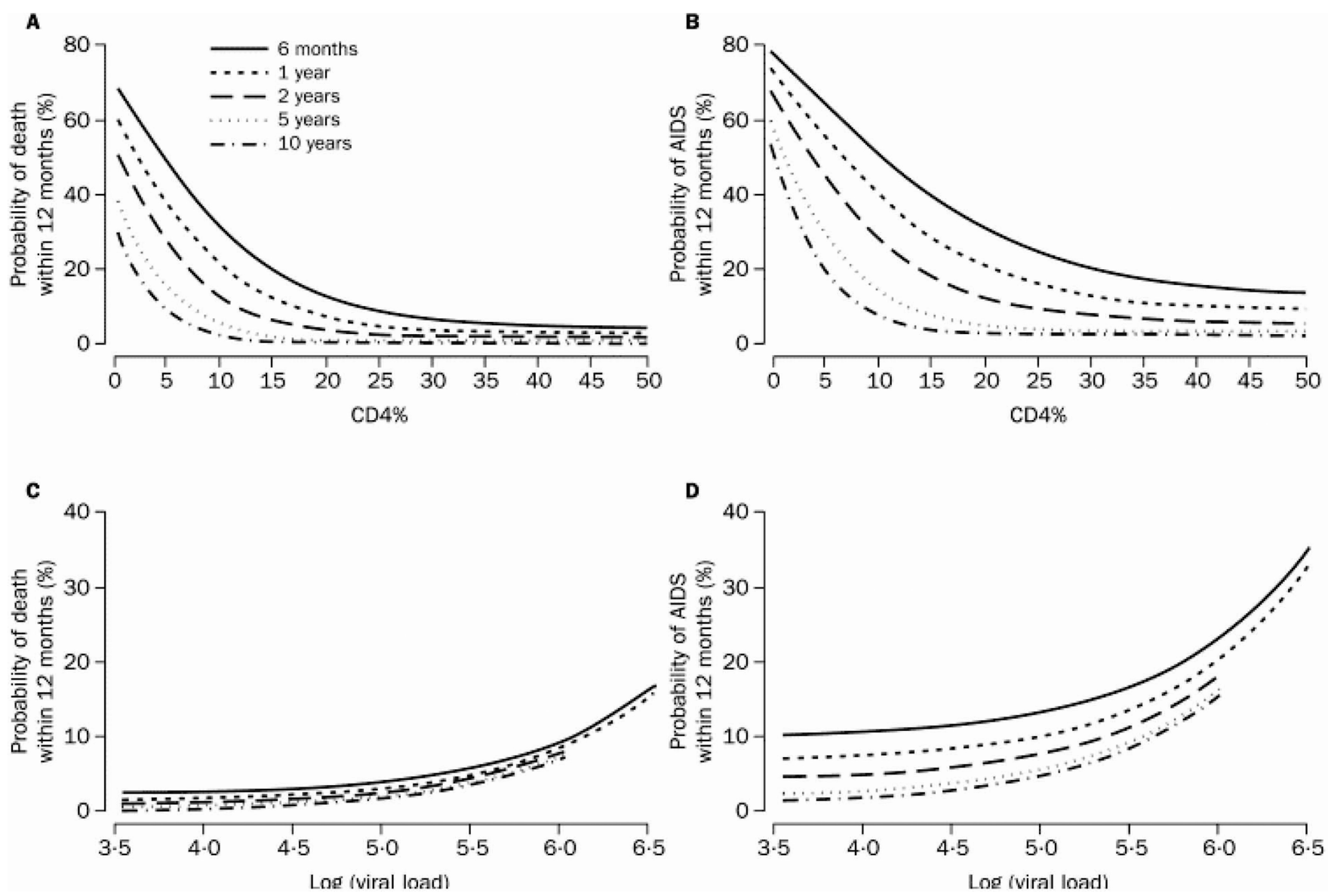

Fig. 4. Distribution of follow-up and events within age groups, for analyses of (A) CD4\% and death, (B) CD4\% and AIDS, (C) viral load and death, (D) viral load and AIDS by age from the HIV Paediatric Prognostic Markers Collaborative Study Group (101) 


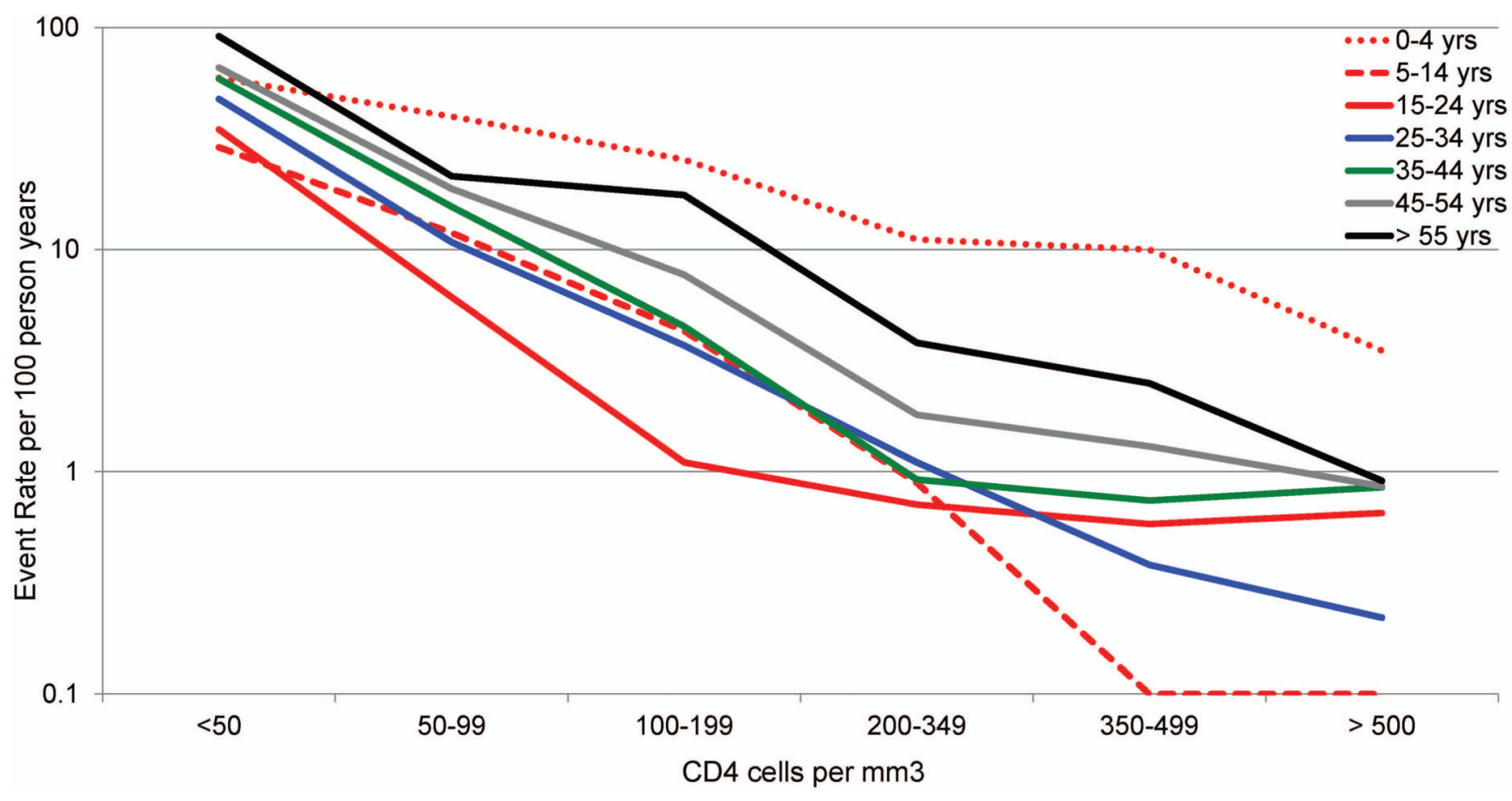

Fig. 5. Death rate per 100 person-years by current $\mathrm{CD4}^{+} \mathrm{T}$-cell count and age Children aged 0-4 years of age have markedly decreased survival even at high CD4 cell counts whereas adolescent and young adults (15-24 years) have a survival advantage. Adapted from Dunn et al (107). 


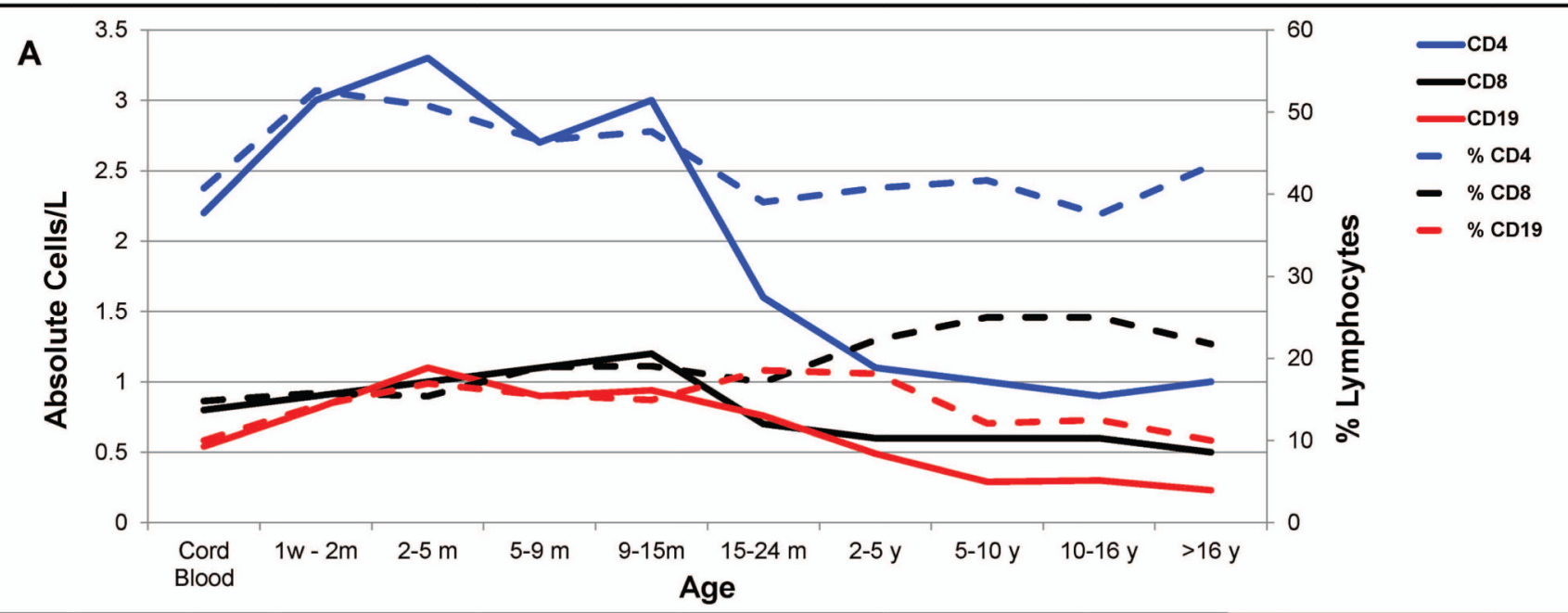

$\mathbf{B}$

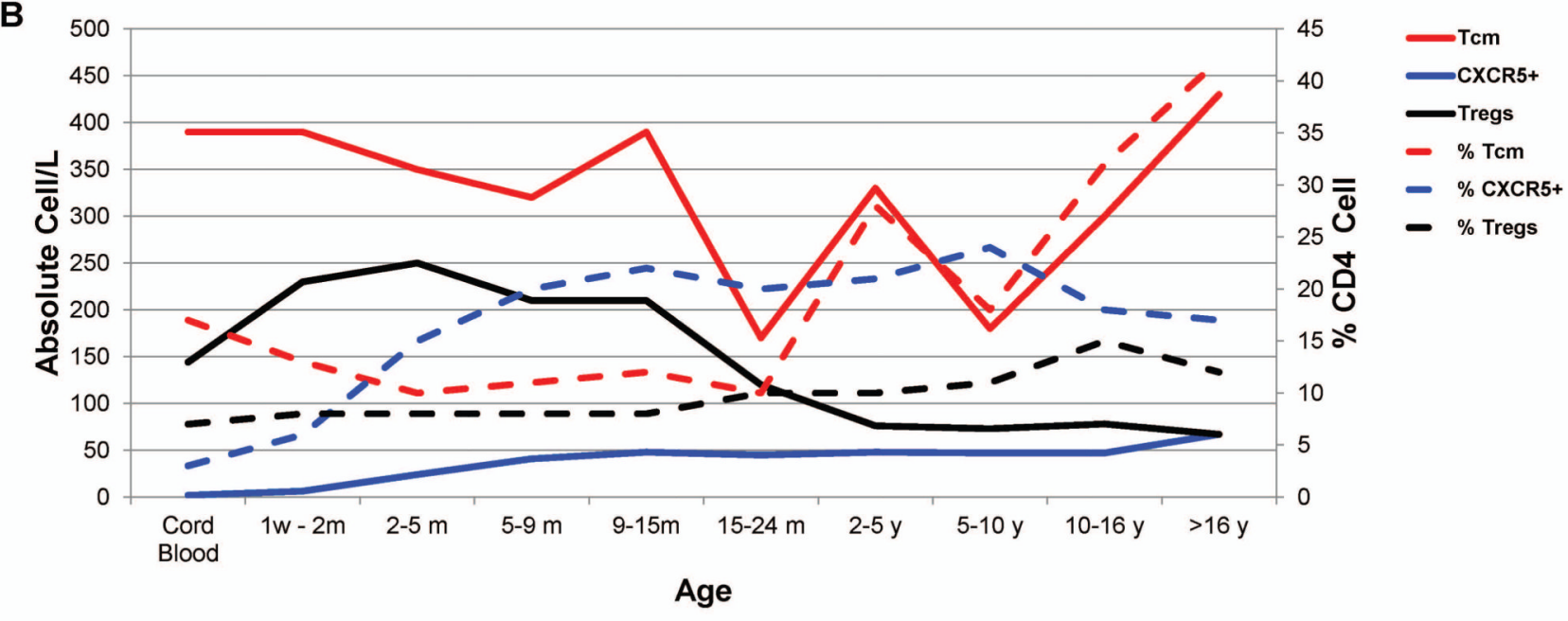

Fig. 6. T-cell populations (Panel A) and $\mathrm{CD4}^{+}$T-cell population subsets (Panel B) by age (A) $\mathrm{CD}^{+} \mathrm{T}$ lymphocytes in blue, $\mathrm{CD} 8^{+} \mathrm{T}$ lymphocytes in black, and CD19+ $\mathrm{B}$ lymphocytes in red by number of cells (solid lines) and percentage of lymphocytes (dotted lines) by age. (B) $\mathrm{Tcm}=$ central memory $\mathrm{T}$ cells $\left(\mathrm{CD} 3^{+} \mathrm{CD} 4{ }^{+} \mathrm{CD} 45 \mathrm{RA}^{-} \mathrm{CD} 27^{+}\right)$in red, $\mathrm{CXCR} 5=$ $\mathrm{CXCR}^{+}$memory helper $\mathrm{T}$ cells $\left(\mathrm{CD} 3^{+} \mathrm{CD} 4^{+} \mathrm{CD} 45 \mathrm{RO}^{+} \mathrm{CD} 185^{+}\right)$in blue, and Tregs $=$ regulatory $\mathrm{T}$ cells $\left(\mathrm{CD} 3{ }^{+} \mathrm{CD} 4^{+} \mathrm{CD} 25^{+} \mathrm{CD} 127^{-}\right)$in black by number of cells (solid lines) and percentage of $\mathrm{CD}^{+} \mathrm{T}$ cells (dotted lines) by age. Adapted from Schartorje et al. (136). 


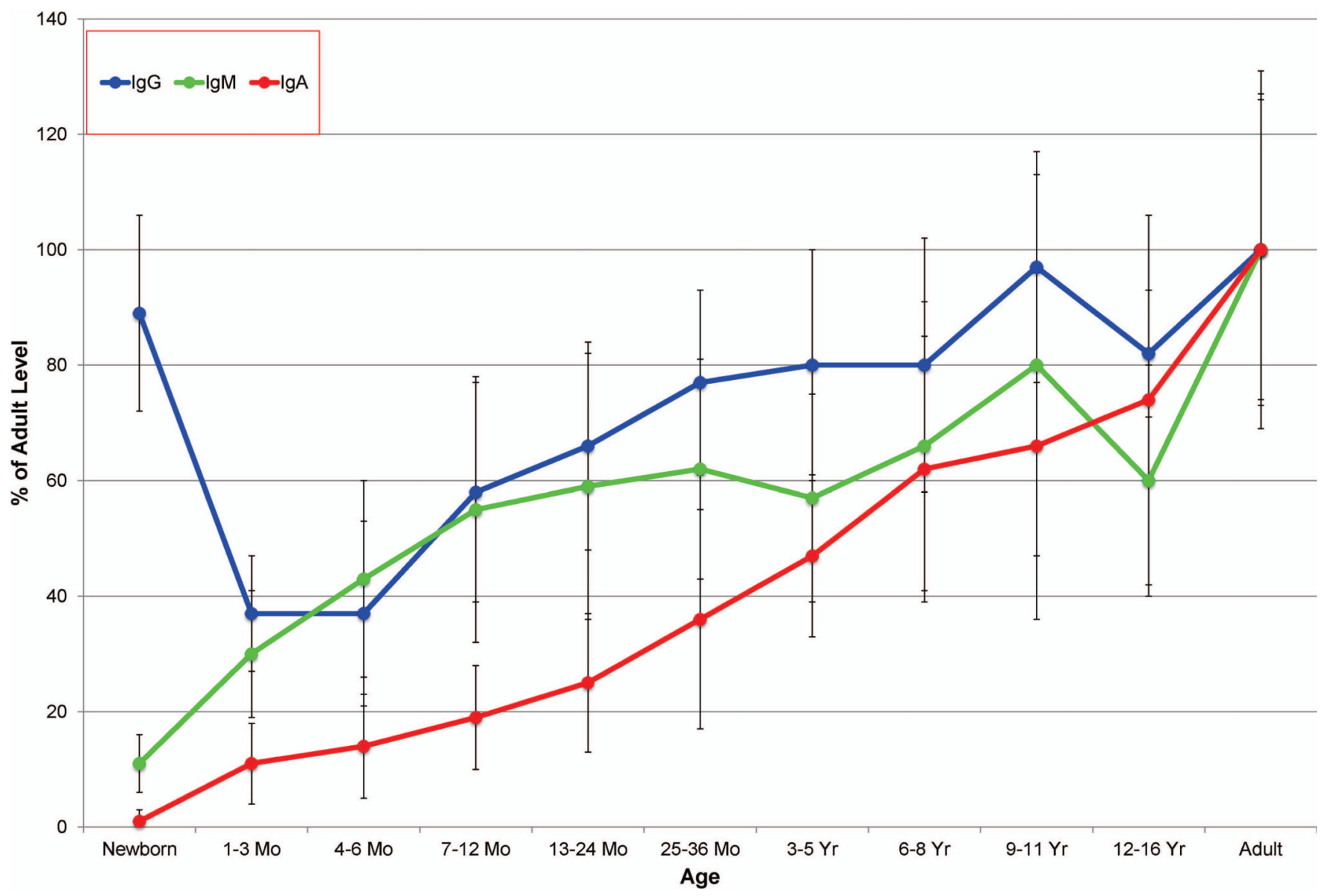

Fig. 7. Percent of adult immunoglobulin levels by age for IgG (blue), IgM (green), and IgA (red) showing significant reduction in immunoglobulin levels in children persisting into adolescence Adapted from Stiehm (138). 



Fig. 8. Development of gut and its immune system with appearance of cellular factors by gestational age

From Insoft et al. (147). 
Table 1

Risks factors for mother-to-child transmission of HIV-1

\begin{tabular}{|c|c|}
\hline Increased transmission & Potential mechanism if known \\
\hline \multicolumn{2}{|l|}{ In Utero $(60,98,368,369)$} \\
\hline Recent Acquisition of HIV-1 & $\begin{array}{l}\text { Greater exposure to virus } \\
\text { Decreased maternal specific HIV-1 immune responses }\end{array}$ \\
\hline Maternal Viral Load (DNA/ RNA & Greater exposure to virus \\
\hline Maternal Hard Drug Use & $\begin{array}{l}\text { Greater exposure to virus due to non-adherence } \\
\text { ?placental breaches } \\
\text { ? increased inflammation }\end{array}$ \\
\hline \multicolumn{2}{|l|}{ Maternal gonorrhea } \\
\hline \multicolumn{2}{|l|}{ Low Birth Weight } \\
\hline Prematurity & $\begin{array}{l}\text { ? Lower levels of maternal immunoglobulin } \\
\text { ? exaggerated intestinal cell response to antigen }\end{array}$ \\
\hline \multicolumn{2}{|l|}{ Low Maternal CD4+ Count } \\
\hline \multicolumn{2}{|l|}{ Placental factors } \\
\hline $\begin{array}{l}\text { - Il-4, IL-5, IL-6, IL-7, IL9, eotoxin, IL-1Ra, IFN gamma-induced } \\
\text { protein } 10 \text { (IP-10) }\end{array}$ & - Elevated in cases in utero MTCT \\
\hline$\bullet$ HLA-G & - Upregulated in cases of MTCT \\
\hline \multicolumn{2}{|l|}{ Intrapartum $(13,60,98,368-371)$} \\
\hline Maternal viral load & Greater exposure to virus \\
\hline Maternal genital HIV DNA Shedding and cell-free RNA & Greater exposure to virus \\
\hline \multicolumn{2}{|l|}{ Prematurity } \\
\hline Chorioamnionitis & $\begin{array}{l}\text { Inflammation resulting in placental breaches greater number of } \\
\text { target cells }\end{array}$ \\
\hline Prolonged rupture of membranes & Greater exposure to virus inflammation \\
\hline \multicolumn{2}{|l|}{ Placental malaria } \\
\hline Maternal Genital Ulcers & Breach of epithelial surface \\
\hline Vaginal candidiasis & Inflammation \\
\hline Infant scalp trauma & Breach of epithelial surface \\
\hline \multicolumn{2}{|l|}{ Breastfeeding (48-51, 58-60, 68, 239-247) } \\
\hline Prematurity & \\
\hline
\end{tabular}




\begin{tabular}{|c|c|}
\hline Increased transmission & Potential mechanism if known \\
\hline Mastitis & Inflammation \\
\hline Breast abscess & Inflammation \\
\hline Cracked or bleeding nipples & Breach of epithelial surface \\
\hline Non-exclusive breast feeding & See text \\
\hline \multicolumn{2}{|l|}{ Parity } \\
\hline Oral thrush & Inflammation \\
\hline \multicolumn{2}{|l|}{ Other Factors $(372,373)$} \\
\hline Toll-like receptor 9 polymorphisms & Suggests role innate immunity \\
\hline Maternal-infant HLA concordance & ? virus pre-selected \\
\hline Decreased Transmission $(41,49,68-70,73,374-376)$ & Potential Mechanism if known \\
\hline Cesarean delivery & Decreased mucosal exposure \\
\hline Antiretroviral therapy & Decreased exposure to virus, ? other Other unknown \\
\hline \multicolumn{2}{|l|}{ Certain CCR5 polymorphisms (infant) } \\
\hline \multicolumn{2}{|l|}{ Protective HLA subtypes } \\
\hline Beta-defensin-1 Polymorphisms & Suggests role innate immunity \\
\hline \multicolumn{2}{|l|}{ Placental factors } \\
\hline • Placental Hofbauer Cells (macrophages) & $\begin{array}{l}\text { - Anti-inflammatory (induce IL-10 and TGF-beta) and } \\
\text { restriction of viral transcription }\end{array}$ \\
\hline - Human beta defensins & •? inhibits viral replication \\
\hline - Leukemia inhibitory factor (LIF) & •? inhibits viral replication \\
\hline Decidual cells of the uterine mucosa & Secrete soluble factors \\
\hline $\begin{array}{l}\text { Breast milk factors } \\
\text { - Low levels of IL-2 } \\
\text { - High Levels of IL-15 } \\
\text { - Alpha-defensins } \\
\text { - Higher concentrations of non-3' -SL Oligosaccharides } \\
\text { - soluble Toll-like receptor } 2 \text { (sTLR2) }\end{array}$ & Immunomodulatory Effects \\
\hline
\end{tabular}


Table 2

Immune factors in breast milk

\begin{tabular}{|c|c|}
\hline Cells & $\begin{array}{l}\text { T cells }-\mathrm{CD}^{+} \text {and } \mathrm{CD} 8^{+} \\
\text {B cells } \\
\text { NK cells } \\
\text { Gamma delta T cells } \\
\text { Stem Cells } \\
\text { Macrophages } \\
\text { Neutrophils }\end{array}$ \\
\hline Immunoglobulins & $\begin{array}{l}\text { Immunoglobulins sIgA (11S and 7S) } \\
\text { IgG, IgM, IgE, IgD } \\
\text { Free secretory component } \\
\text { Anti-idiotypes } \\
\text { Anti CCR5 antibodies }\end{array}$ \\
\hline Cytokines, chemokines, and receptors & 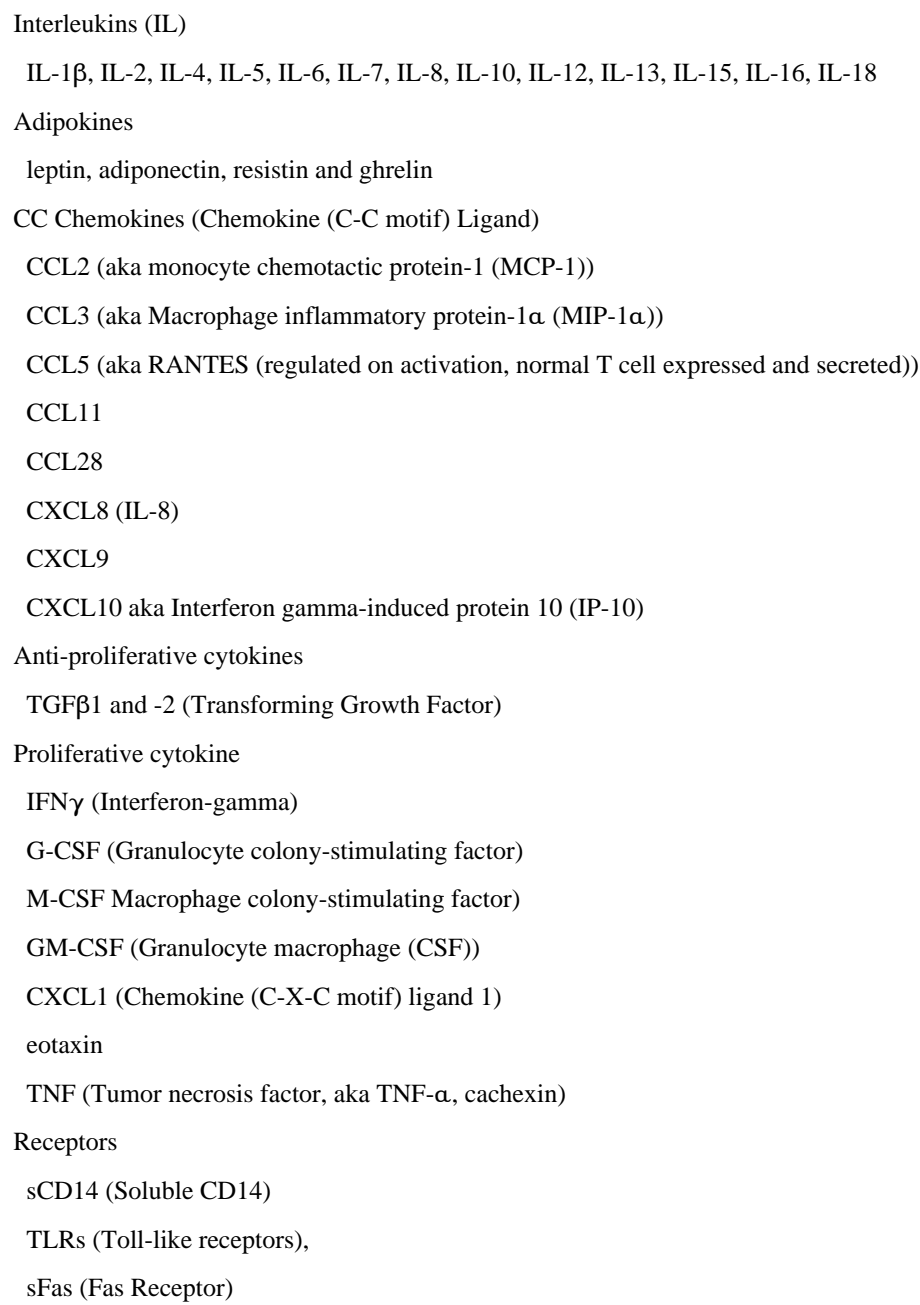 \\
\hline
\end{tabular}




\begin{tabular}{|c|c|}
\hline & $\begin{array}{l}\text { sFasL (soluble Fas Ligand) } \\
\text { IL-1 Receptor antagonist } \\
\text { soluble TNFa receptors I and II (Tumor Necrosis Factor alpha) } \\
\text { ICAM-1 (Soluble intracellular adhesion molecule 1) } \\
\text { VCAM-1 (Soluble vascular cell adhesion molecule 1) }\end{array}$ \\
\hline Regulators of gene expression Innate Immunity & $\begin{array}{l}\text { miRNA } \\
\text { Exosomes } \\
\text { Complement C1-C9) } \\
\text { properdin factors) } \\
\text { MBL (mannose binding lectin) }\end{array}$ \\
\hline Anti-bacterial and Anti-viral factors & $\begin{array}{l}\beta \text {-defensin-1 } \\
\text { Fatty acids } \\
\text { Haemagglutinin inhibitors } \\
\text { lactoferrin } \\
\text { Monoglycerides } \\
\text { Secretory leukocyte protease inhibitor (antileukocyte protease; SLPI) }\end{array}$ \\
\hline Hormones and Growth Factors & $\begin{array}{l}\text { epidermal growth factor (EGF), } \\
\text { nerve growth factor (NGF), } \\
\text { insulin-like growth factors (IGFs), } \\
\text { vascular-endothelial growth factor } \\
\text { a-fetoprotein (glycoprotein) } \\
\text { Adrenocorticotropin } \\
\text { Bombesin } \\
\text { Corticoid-binding protein } \\
\text { cortisol } \\
\text { erythropoietin (glycoprotein) } \\
\text { Glucocorticoids } \\
\text { Gonadotropins } \\
\text { Insulin } \\
\text { Neurotensin } \\
\text { Ovarian steroids } \\
\text { Prolactin } \\
\text { Prostaglandins E1, E2, F2 alpha } \\
\text { Relaxin } \\
\text { Somatostatin } \\
\text { Thyroid-releasing hormone } \\
\text { Thyroid-stimulating hormone } \\
\text { Thyroxin }\end{array}$ \\
\hline Anti-oxidants & $\begin{array}{l}a \text {-tocopherol } \\
\beta \text {-carotene } \\
\text { catalase }\end{array}$ \\
\hline
\end{tabular}




\begin{tabular}{|c|c|}
\hline & $\begin{array}{l}\text { glutathione peroxidase } \\
\text { lutein, } \\
\text { vitamin E }\end{array}$ \\
\hline Anti-adherence substances & $\begin{array}{l}\text { glycolipids (Gb3, Gb) } \\
\text { glycosaminoglycans } \\
\text { chondroitin sulfate } \\
\text { kappa-casein } \\
\text { Lactadherin (milk fat globule-EGF factor 8) } \\
\text { Mucins } \\
\text { MUC1 (Mucin 1, cell surface associated) } \\
\text { Oligosaccharides } \\
\text { Fucosylated oligosaccharides } \\
\text { Sialyllactose }\end{array}$ \\
\hline $\begin{array}{l}\text { Electrolytes, Vitamins, Minerals, Trace metals } \\
\text { and Amino Acids }\end{array}$ & $\begin{array}{l}\text { Biotin } \\
\text { Boron } \\
\text { Calcium } \\
\text { Chloride } \\
\text { Choline } \\
\text { Copper } \\
\text { Fluoride } \\
\text { Folate } \\
\text { Glutamine } \\
\text { Inositol } \\
\text { Iodine } \\
\text { Iron } \\
\text { Maganese } \\
\text { Magnesium } \\
\text { Niacin } \\
\text { Pantothenic acid } \\
\text { Phosphorus } \\
\text { Potassium } \\
\text { Selenium } \\
\text { Sodium } \\
\text { Thiamine (B1) } \\
\text { vitamin A } \\
\text { vitamin B6 } \\
\text { vitamin B12 } \\
\text { vitamin C } \\
\text { vitamin D } \\
\text { vitamin E } \\
\text { vitamin K } \\
\text { Zinc }\end{array}$ \\
\hline
\end{tabular}




\begin{tabular}{|c|c|}
\hline Bacteria (select) & $\begin{array}{l}\text { Bifidobacterium bifidum } \\
\text { Lactic Acid Bacilli } \\
\text { Streptococcus } \\
\text { Staphylococcus } \\
\text { Serratia } \\
\text { Corynebacteria }\end{array}$ \\
\hline Enzymes & $\begin{array}{l}\text { antiproteases } \\
\text { Lactoperoxidase } \\
\text { leukocyte enzymes } \\
\text { Lipoprotein lipase } \\
\text { Lysozyme } \\
\text { platelet-activating factor-acetyl-hydrolase } \\
\text { Ribonuclease } \\
\text { Xanthine oxidase }\end{array}$ \\
\hline Carrier proteins & $\begin{array}{l}\text { Lactoferrin } \\
\text { Steroid binding protein } \\
\text { Transferrin } \\
\text { vitamin B-12 binding protein }\end{array}$ \\
\hline Other (or multiple classifications) & $\begin{array}{l}\text { Carbohydrates } \\
\text { Caseins } \\
\text { alpha-lactoglobulin } \\
\text { alpha2-macroglobulin (like) } \\
\text { (Tri to penta) phosphorylated beta-casein } \\
\text { Gangliosides (GM1-3, GD1a, GT1b, GQ1b) } \\
\text { Glycopeptides } \\
\text { Glycoproteins (other) } \\
\text { CD59 glycoprotein aka MAC-inhibitory protein (MAC-IP) } \\
\text { Glycoproteins (mannosylated) } \\
\text { Glycoproteins (receptor-like) } \\
\text { Glycoproteins (sialic acid-containing or terminal galactose) } \\
\text { Heparin } \\
\text { LALBA (Lactalbumin alpha) } \\
\text { Lewis Antigens } \\
\text { Lipids (other) } \\
\text { Long-chain polyunsaturated fatty acids } \\
\text { MIP (macrophage migration inhibitory factor) } \\
\text { Nucleotides } \\
\text { Phosphatidylethanolamine } \\
\text { Prostaglandin } \\
\text { Sulfatides } \\
\text { Trypsin Inhibitor }\end{array}$ \\
\hline
\end{tabular}


Table 3

Neonatal Immune System

\begin{tabular}{|c|c|}
\hline Innate Immunity & $\begin{array}{l}\text { Increased IL-10 production } \\
\text { Decreased IFN-gamma and IL-12 production } \\
\text { Increased IL-6, IL-23, and IL-1 beta production } \\
\text { Favors extracellular bacterial pathogen protection }\end{array}$ \\
\hline Phagocytes & $\begin{array}{l}\text { Decreased production of phagocytes } \\
\text { Poor adhesion molecule function } \\
\text { Abnormal migration across endothelial barriers } \\
\text { Inadequate chemotactic response } \\
\text { Deficits in hydroxyl radical production } \\
\text { Decreased phagocytes at site of infection }\end{array}$ \\
\hline Cell-mediated Immunity & $\begin{array}{l}\text { Decreased mature memory } \mathrm{T} \text { cells in blood } \\
\text { Restricted development of Th1 lymphocytes } \\
\text { Decreased T helper function } \\
\text { Increased differentiation of regulatory T cells } \\
\text { Increased differentiation of Th2 lymphocytes } \\
\text { Decreased cytokine production } \\
\text { - IFN-alpha, IL2, IL-4, IL-10 } \\
\text { Decreased NK cell ADCC } \\
\text { Poor stimulation of B cells }\end{array}$ \\
\hline B-lymphocytes and Immunoglobulins & $\begin{array}{l}\text { Decreased antibody production } \\
\text { Poor isotype switching } \\
\text { Decreased Ab affinity } \\
\text { Decreased total antibody \& antibody subtypes (Figure 7) } \\
\text { Deficient opsonization by immunoglobulins } \\
\text { Poor response to polysaccharides }\end{array}$ \\
\hline Complement Cascade & $\begin{array}{l}\text { Decreased function of classic and alternative pathways } \\
\text { Low levels of C5a }\end{array}$ \\
\hline
\end{tabular}

IL - interleukin; IFN - interferon; Th1 - T helper 1 lympocytes; Th2 - T helper 2 lymphocytes; NK - natural killer cell 